\title{
Enhanced $A_{3}$ adenosine receptor selectivity of multivalent nucleoside-dendrimer conjugates
}

\author{
Athena M Klutz ${ }^{1}$, Zhan-Guo Gao ${ }^{1}$, John Lloyd ${ }^{2}$, Asher Shainberg ${ }^{3}$ and \\ Kenneth A Jacobson*1
}

Address: ${ }^{1}$ Molecular Recognition Section, Laboratory of Bioorganic Chemistry, National Institute of Diabetes and Digestive and Kidney Diseases, Bethesda, Maryland 20892, USA, ${ }^{2}$ Mass Spectrometry Facility, Laboratory of Bioorganic Chemistry, National Institute of Diabetes and Digestive and Kidney Diseases, Bethesda, Maryland 20892, USA and ${ }^{3}$ Faculty of Life Sciences, Bar-Ilan University, Ramat Gan, Israel

Email: Athena M Klutz - KlutzA@niddk.nih.gov; Zhan-Guo Gao - ZhanguoG@niddk.nih.gov; John Lloyd - lloydj@niddk.nih.gov; Asher Shainberg - shaina@mail.biu.ac.il; Kenneth A Jacobson* - kajacobs@helix.nih.gov

* Corresponding author

Published: 23 October 2008

Journal of Nanobiotechnology 2008, 6:12 doi:10.1186/1477-3155-6-12
Received: 13 August 2008

Accepted: 23 October 2008

This article is available from: http://www.jnanobiotechnology.com/content/6/1/12

(c) 2008 Klutz et al; licensee BioMed Central Ltd.

This is an Open Access article distributed under the terms of the Creative Commons Attribution License (http://creativecommons.org/licenses/by/2.0), which permits unrestricted use, distribution, and reproduction in any medium, provided the original work is properly cited.

\begin{abstract}
Background: An approach to use multivalent dendrimer carriers for delivery of nucleoside signaling molecules to their cell surface $G$ protein-coupled receptors (GPCRs) was recently introduced.

Results: A known adenosine receptor (AR) agonist was conjugated to polyamidoamine (PAMAM) dendrimer carriers for delivery of the intact covalent conjugate to on the cell surface. Depending on the linking moiety, multivalent conjugates of the $N^{6}$-chain elongated functionalized congener ADAC (N6-[4-[[[4-[[[(2-aminoethyl)amino]carbonyl]methyl]anilino]carbonyl]methyl]phenyl]adenosine) achieved unanticipated high selectivity in binding to the cytoprotective human $A_{3} A R$, a class A GPCR. The key to this selectivity of $>100$-fold in both radioreceptor binding $\left(K_{i \text { app }}=2.4\right.$ $\mathrm{nM})$ and functional assays $\left(\mathrm{EC}_{50}=1.6 \mathrm{nM}\right.$ in inhibition of adenylate cyclase) was maintaining a free amino group (secondary) in an amide-linked chain. Attachment of neutral amide-linked chains or thiourea-containing chains preserved the moderate affinity and efficacy at the $A, A R$ subtype, but there was no selectivity for the $A_{3} A R$. Since residual amino groups on dendrimers are associated with cytotoxicity, the unreacted terminal positions of this $A_{3} A R$-selective $G 2.5$ dendrimer were present as carboxylate groups, which had the further benefit of increasing water-solubility. The $A_{3}$ AR selective G2.5 dendrimer was also visualized binding the membrane of cells expressing the $A_{3}$ receptor but did not bind cells that did not express the receptor.
\end{abstract}

Conclusion: This is the first example showing that it is feasible to modulate and even enhance the pharmacological profile of a ligand of a GPCR based on conjugation to a nanocarrier and the precise structure of the linking group, which was designed to interact with distal extracellular regions of the 7 transmembrane-spanning receptor. This ligand tool can now be used in pharmacological models of tissue rescue from ischemia and to probe the existence of $A_{3} A R$ dimers. 


\section{Background}

Dendrimers bearing multiple ligands may have increased avidity to a receptor compared to the monovalent ligand, particularly if the ligand has a weak affinity for the receptor [1]. While this phenomenon has only been loosely demonstrated with PAMAM dendrimers, it is well established that multivalent oligo- and poly-saccharides, including PAMAM glycodendrimers, show some enhancement in binding compared to the monovalent saccharide, which is known as the cluster glycoside effect [2]. Dendrimer-ligand complexes have also been used as imaging agents [3] and for gene delivery [1]. Recently, we also attached CGS21680, an $\mathrm{A}_{2 \mathrm{~A}}$ adenosine receptor (AR) agonist, to G3 PAMAM dendrimers, providing the first example of a GPCR ligand to be conjugated covalently to a dendrimer while retaining its biological activity [4].

The ARs are GPCRs that have a generally cytoprotective role and their ligands are of increasing therapeutic interest. The $A_{1} A R$ and $A_{3} A R$ inhibit adenylyl cylase through the coupling of the $G_{i}$ protein and are also involved in activating phospholipase $\mathrm{C}$ and potassium channels [5]. The $A_{1} A R$ is highly expressed in the brain, spinal cord, eye, and atria while intermediate expression is found in the liver, kidney, and adipose tissue [6]. The $\mathrm{A}_{3} \mathrm{AR}$ is upregulated in peripheral blood mononuclear cells of patients with rheumatoid arthritis as well as in several breast, colon and pancreatic carcinoma tissues [7], but more studies are needed to learn about the expression of this protein in normal patients. Preconditioning of cardiomyocytes with either $A_{1}$ or $A_{3} A R$ agonists protects against myocardial ischemia. This cardioprotection occurs through extracellular signal-regulated kinase (ERK) signaling and activation of the mitochondrial $\mathrm{K}^{+}$-ATP channels [5]. $A_{1}$ AR agonists also inhibit lipolysis [6] and may act as anti-epileptic agents [8], while $\mathrm{A}_{3} \mathrm{AR}$ agonists may protect against lung injury and cancer $[9,10]$.

The AR ligands chosen for conjugation to both G2.5 or G3 PAMAM dendrimers in the present study are the $\mathrm{A}_{1} \mathrm{AR}$ agonist $\quad N^{6}$-[4-[[[4-[[](2-aminoethyl)amino]carbonyl]methyl]anilino]-carbonyl]methyl]phenyl]adenosine (ADAC, 1) and related functionalized congeners (Figure 1). Functionalized congeners are designed by adding a chain substituent to a pharmacophore in a strategic, permissive location so that conjugation to other large mole-

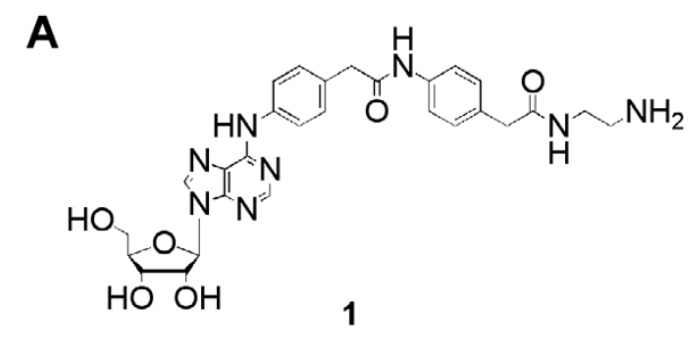

\section{B}

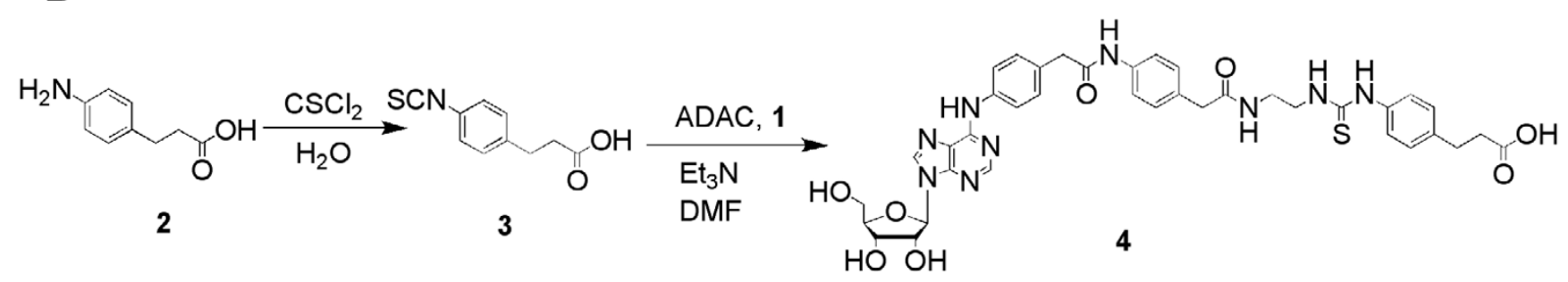

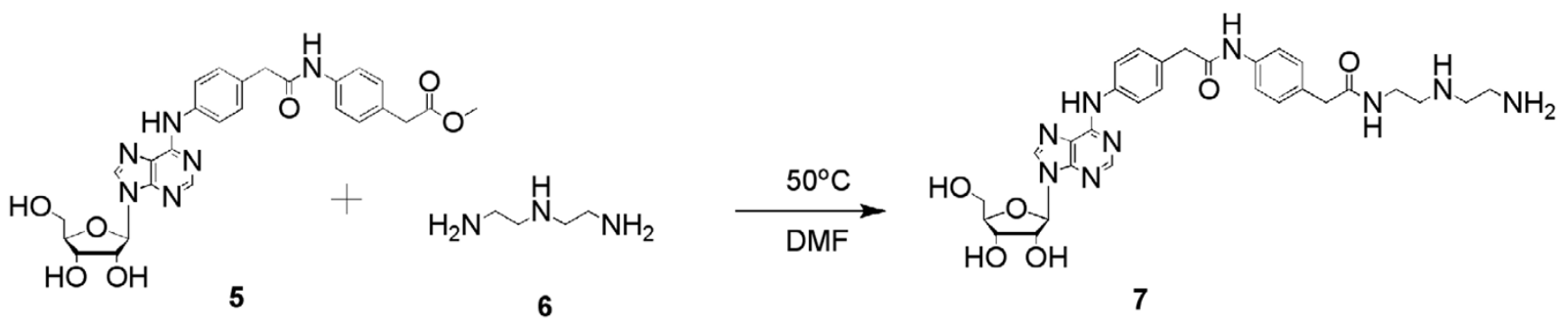

Figure I

Synthesis of novel functionalized congener monomers related to ADAC. 
cules is possible [11]. Ideally, the linker is modified to enhance the interaction of the pharmacophore with the receptor. This approach has been used to study $A_{1}$ [12], $A_{2 A}$ [13], and $A_{3}$ ARs [11]. ADAC is a highly selective $A_{1} A R$ agonist at the rat ARs and also displays some selectivity towards the human $\mathrm{A}_{1} \mathrm{AR}$ and human $\mathrm{A}_{3} \mathrm{AR}$ in comparison to the human $A_{2 A} A R[5,14]$. ADAC protects against neuronal damage and mortality after either acute or chronic administration prior to a ten-min bilateral cerebrovascular occlusion in gerbils. Significantly higher doses of other $A_{1} A R$ agonists are needed to produce an equivalent effect [15]. ADAC also provides neuronal protection when given up to twelve hours post-ischemia [16]. Each of the dendrimer nucleoside conjugates also contained a fluorescent moiety for in vitro and in vivo localization.

\section{Results}

This study was designed to probe the feasibility of modulating the potency and selectivity of nucleoside agonist ligands of ARs based on conjugation to a PAMAM nanocarrier.

\section{Synthesis of ADAC-Related Functionalized Congeners and Dendrimer Conjugates}

ADAC, an amine-derivatized nucleoside that potently binds to and activates the $A_{1} A R$, was coupled covalently to the surface of polyamidoamine (PAMAM) dendrimers of generation 2.5 (G2.5). Two other linker moieties were applied for comparison: one containing a secondary amine and another containing an extended arylthiourea group, which was attached to a G3 PAMAM dendrimer as shown in Figure 1B. Two nucleoside intermediates related to ADAC, 4 and 7, which had chains that could be coupled to PAMAM dendrimers, were synthesized as shown in Figure 1. 3-(p-Aminophenyl)propanoic acid 2 was converted to 3-(p-isothiocyanatophenyl)propanoic acid 3 by addition of thiophosgene in aqueous medium. The isothiocyanate group of 3 was then conjugated to the terminal amino group of ADAC to form a thiourea linkage in 4, which had a terminal carboxyl group that could be coupled to the amino group of the G3 PAMAM dendrimer. To synthesize the diamino derivative 7 , diethylenetriamine $\mathbf{6}$ was heated with methyl ester $\mathbf{5}$, which was similar to a previous method [17]. This product has a terminal primary amine group that was coupled to the G2.5 PAMAM dendrimer, with preference for its acylation over the secondary amine.

Each of the G3 and G2.5 dendrimer conjugates also contained an AlexaFluor 488 (AF488) moiety [18] for fluorescent detection. G3-PAMAM-AF488-3 4 (12) and G3PAMAM-AF488-8 4 (13) were synthesized as shown in Figure 2. First, the G3 dendrimer was partially acetylated with acetic anhydride to decrease toxicity. Next, the AlexaFluor 488 moiety was attached using either a PyBOP coupling in the presence of triethylamine as base [4] or an EDC coupling at pH $5[19,20]$. Finally, an amide bond was formed between the carboxyl group of 2 and several terminal amines on the G3 dendrimer using a PyBOP coupling for 13 [4] and an EDC coupling for $12[19,20]$.

Another goal was to compare 2.5 PAMAM - conjugates of $\mathrm{A}_{1}$ AR agonists with G3 PAMAM - conjugates of similar agonists. However, in order to attach AF488 to the carboxylic G2.5 dendrimer, it was necessary to synthesize a new

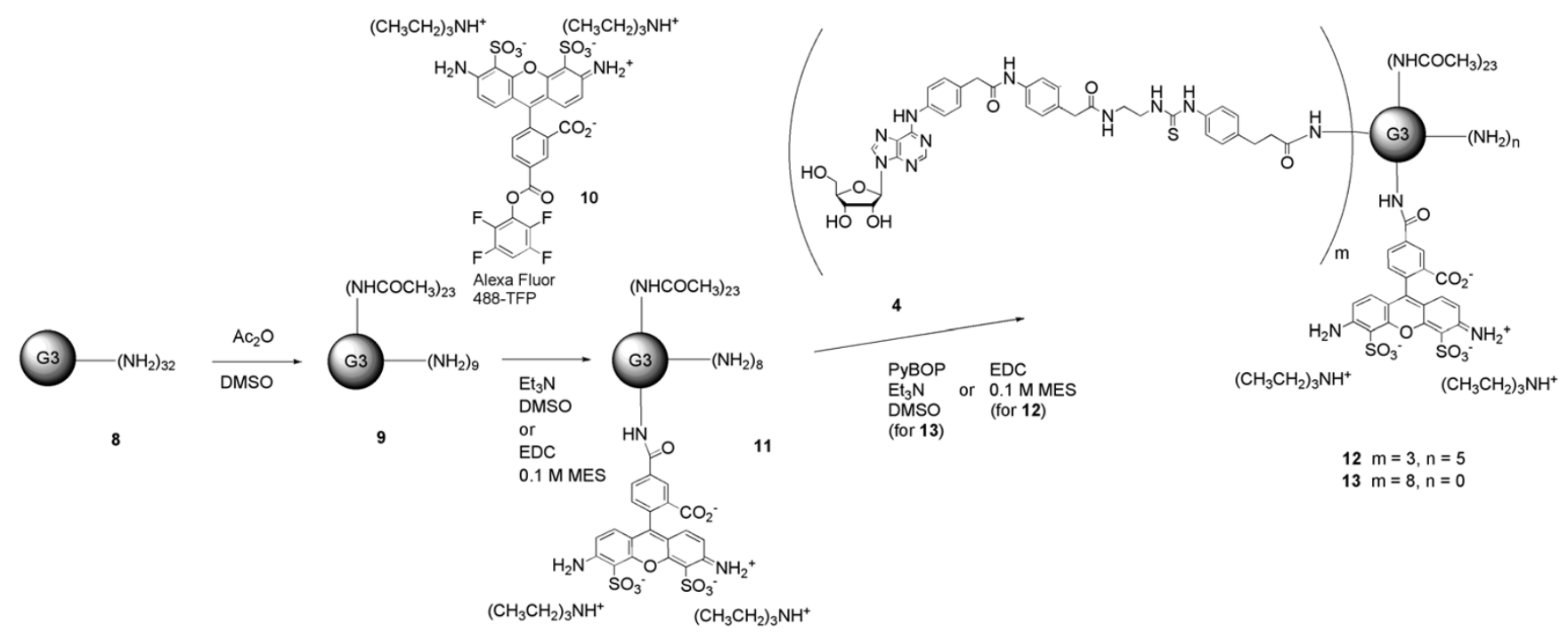

Figure 2

Synthesis of compounds 12 and 13 - derivatives of G3 PAMAM dendrimer. 
AF488 derivative having a terminal primary amine. Initial attempts were made to couple ethylenediamine to $\mathbf{1 0}$ using triethylamine in DMF or DMSO, but the AF488 did not appear stable under these conditions. However, a variation of the method using ethylenediamine in $0.1 \mathrm{M}$ $\mathrm{NaB}_{4} \mathrm{O}_{7}, \mathrm{pH} 8.5$, was successful. After HPLC purification and lyophilization, compound 14 was isolated in $93 \%$ yield.

G2.5-PAMAM-AF488-1 (16) and G2.5-PAMAM-AF488-7 (17) were synthesized as shown in Figure 3. First, a carbodiimide coupling was used to attach the AF488 derivative 14 to the G2.5 dendrimer, using EDC in $0.1 \mathrm{M}$ MES, pH 5 $[19,20]$. The unreacted EDC and urea byproduct were removed by dialysis. Next, the terminal amino groups of either 1 or 7 were amide conjugated to the G2.5 dendrimer also using a carbodiimide coupling.

The conjugates were purified using size exclusion chromatography and characterized using NMR and electrospray ionization (ESI) mass spectrometry (MS) (see Additional file 1). The parent G3 dendrimer matched its theoretical weight, but the parent G2.5 dendrimer appeared to be missing 2 propionate groups in the largest peak in the mass spectrum, as shown in Figure S1 (Additional file 1). Due to the excessive amount of sodium, the G2.5 spectrum was significantly more fragmented than the G3 spectrum. These spectra appear to be one of the first examples of using ESI MS rather than MALDI MS to obtain data on the PAMAM dendrimers.

After removal of the monomers by dialysis, NMR showed that approximately three and eight molecules of 4 were attached per dendrimer, on average, in derivatives 12 and 13, respectively. Interestingly, while the mass spectrum of 13 was very close to the theoretical mass, the mass spectrum of both compounds was very fragmented as shown in Figure S2 (Additional file 1). The largest peak of 12 appeared to differ from the theoretical mass by approximately $1.8 \%$, possibly due to the molecule breaking down in the mass spectrometer. The majority of the amino groups on the dendrimer appeared to be acylated, which has previously been shown to significantly decrease toxicity [21].
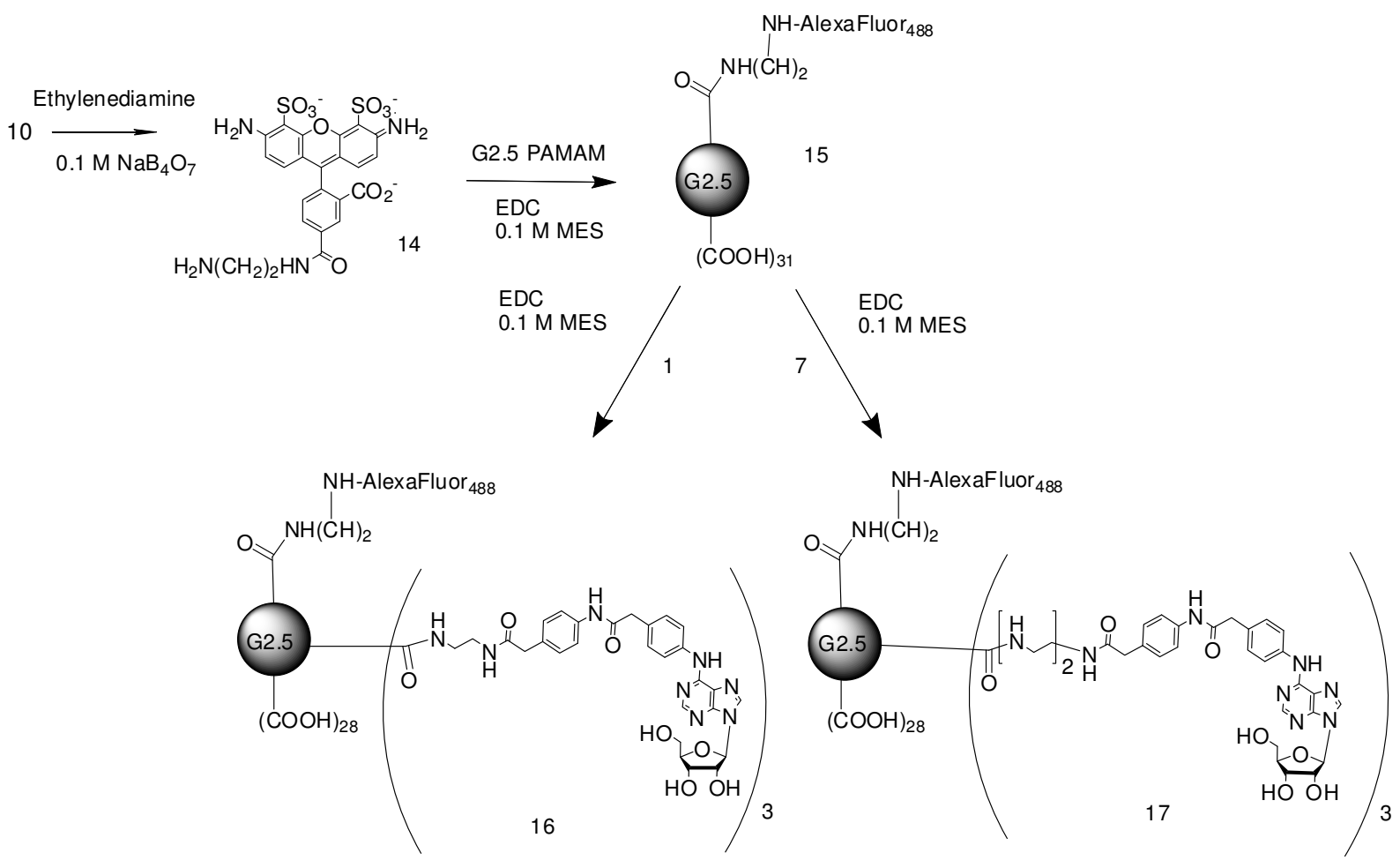

Figure 3

Synthesis of compounds 16 and 17 - derivatives of G2.5 PAMAM dendrimer. 
NMR indicated that on average there were approximately three nucleoside ligand moieties attached to each dendrimer in purified derivatives $\mathbf{1 6}$ and $\mathbf{1 7}$. The mass spectrum of $\mathbf{1 6}$ was different from the theoretical mass by approximately 1 nucleoside moiety, possibly due to the compound decomposing in the mass spectrometer. The mass spectrum of 17 was too fragmented to be useful as shown in Figure S3 (Additional file 1). The largest peak in the spectra was smaller than 15 , the dendrimer with only the AF488 moiety attached. However, smaller peaks in the spectrum were closer to the theoretical weight. Unlike the spectra for 13 and 14, there was significantly more sodium in these spectra, which may have caused the difficulties in obtaining these spectra. Also, the parent G2.5 dendrimer had more fragmentation than the parent G3 dendrimer. The difficulty in obtaining mass spectral data for dendrimers is a known phenomenon [21].

\section{Pharmacological Characterization of ADAC-Related Functionalized Congeners}

The human AR binding affinity of these functionalized congeners was measured prior to attachment to the dendrimers (Table 1) [22]. Both 4 and 7, the new ADAC derivatives, had slightly lower affinity than ADAC itself at the $\mathrm{A}_{1} \mathrm{AR}$, with $\mathrm{K}_{\mathrm{i} \text { app }}$ values of $30 \mathrm{nM}$ and $43 \mathrm{nM}$, respectively. While 4 retained selectivity similar to ADAC towards the $A_{1} A R$ in comparison to $A_{2 A} A R, 7$ was slightly less selective. Interestingly, 7 had a similar affinity for the $A_{3} A R$ as ADAC, while 4 had significantly lower affinity at this receptor. [ $\left.{ }^{35 S}\right] \mathrm{GTP} \gamma \mathrm{S}$ binding, a functional assay for $\mathrm{G}_{i}$ protein activation [23], was completed in membranes expressing the $A_{1} A R$ (Table 2). Compound 7, with an $\mathrm{EC}_{50}$ value of $63 \mathrm{nM}$ in activation of GTP $\gamma \mathrm{S}$ binding via the

Table I: $K_{i}$ apparent values for binding of nucleoside monomers and dendrimer conjugates at $A_{1}, A_{2 A}$, and $A_{3} A R s .^{a}$

\begin{tabular}{|c|c|c|c|}
\hline Compound & $A_{1} K_{i}(n M)$ & $\mathbf{A}_{2 \mathrm{~A}} \mathrm{~K}_{\mathrm{i}}(\mathrm{nM})$ & $A_{3} K_{i}(n M)$ \\
\hline \multicolumn{4}{|c|}{ Nucleoside Monomers } \\
\hline $\mathbf{I}$ & $10.4 \pm 3.8$ & $370 \pm 100$ & $12.2 \pm 4.1$ \\
\hline $4^{d}$ & $30 \pm 9$ & $800 \pm 360$ & $74 \pm 20$ \\
\hline $7^{d}$ & $43 \pm 5$ & $300 \pm 20$ & $9.5 \pm 2.0$ \\
\hline \multicolumn{4}{|c|}{ Dendrimer Derivatives } \\
\hline II & $N^{b}$ & $(20 \pm 7 \%)^{c}$ & $(26 \pm 3 \%)^{c}$ \\
\hline 12 & $21 \pm 5$ & $250 \pm 40$ & $27 \pm 2$ \\
\hline 13 & $55 \pm 10$ & $405 \pm 170$ & $42 \pm 17$ \\
\hline 15 & $N B^{b}$ & $\mathrm{NB}^{\mathrm{b}}$ & $N B^{b}$ \\
\hline 16 & $175 \pm 60$ & $610 \pm 110$ & $14.0 \pm 2.1$ \\
\hline $17^{d}$ & $320 \pm 20$ & $470 \pm 50$ & $2.4 \pm 0.4$ \\
\hline
\end{tabular}

a. All experiments were performed using adherent $\mathrm{CHO}$ cells stably expressing the $A_{1}$ or $A_{3} A R$ or HEK cells stably expressing $A_{2 A} A R$. Binding was carried out as described in methods using $\left[{ }^{3} \mathrm{H}\right] C \mathrm{CPA}$, $\left[{ }^{3} \mathrm{H}\right]$ CGS2I 680 , or [ $\left.{ }^{125} \mathrm{I}\right] \mathrm{AB}-\mathrm{MECA}$. Values are expressed as $\mathrm{K}_{\mathrm{i}}$ values (mean \pm SEM, $n=3$ ) or as displacement of the radioligand at $10 \mu \mathrm{M}$. b. NB, No binding. Inhibition of radioligand binding < 10\% at $10 \mu \mathrm{M}$. c. Percent inhibition of radioligand binding at $10 \mu \mathrm{M}$. d. 4, MRS5I45; 7, MRS5169; 17, MRS5I83.
$A_{1} A R$, was 20-fold more potent than 4 and slightly more potent than ADAC. In an assay measuring the inhibition of the production of cAMP (Table 2), compound 7 was also the most potent monomer at the $\mathrm{A}_{1}$ and $\mathrm{A}_{3}$ ARs. Compound 7 was $3-7$ fold more potent in adenylyl cyclase assays at these two ARs than either ADAC or 4, which were nearly equipotent at both the $A_{1}$ and $A_{3}$ ARs. All compounds were shown to be full agonists at the $A_{1}$ and $A_{3}$ ARs in both assays.

\section{Pharmacological Characterization of Nuceloside- Dendrimer (G3) Conjugates}

In the radioligand binding studies, the G3 dendrimer-ligand conjugates 12 and $\mathbf{1 3}$ had a comparable affinity to the free monomer 4 at the $A_{1} A R$, but maintained a lower degree of $A_{1}$ selectivity compared to the $A_{2 A} A R$. However, both conjugates had a higher affinity at the $A_{3}$ AR than the free monomer. The control dendrimer, 11, which contained AF488 and multiple acetamide moieties but not the nucleoside ligand, showed no binding at the $A_{1} A R$. At the $A_{2 A}$ and $A_{3} A R s$, weak binding inhibition was evident at $10 \mu \mathrm{M}$, which might be a result of association of the radioligand with the dendrimer conjugate at high concentrations. This phenomenon was seen in the $\mathrm{A}_{2 \mathrm{~A}} \mathrm{AR}$ agonist-dendrimer conjugates as well [24]. The control dendrimer 11 also showed slight activity at $10 \mu \mathrm{M}$ in the stimulation of [ ${ }^{35}$ S]GTP $\gamma S$ binding. However, at $10 \mu \mathrm{M}, 11$ was unable to significantly inhibit CAMP production at the $A_{1} A R$ or the $A_{3} A R$. In an assay measuring [ ${ }^{35}$ S]GTY $\gamma S$ binding at the $A_{1} A R$, the $G 3$ dendrimer ligand conjugates 12 and 13 had $\mathrm{EC}_{50}$ values that were at least 4 fold lower than the free monomer. Both of the dendrimer ligand conjugates 12 and 13 were almost 5 - 10 fold more potent at the $A_{1} A R$ than the free monomer in an assay measuring inhibition of CAMP production. Therefore, conjugating the nucleoside 4 to the dendrimer improved the potency in activation of the $A_{1} A R$ even though the affinity was similar in the radioligand binding.

\section{Pharmacological Characterization of Nuceloside- Dendrimer (G2.5) Conjugates}

Radioligand binding was completed for each of the G2.5 dendrimer conjugates. Compound 17 showed a $2.4 \mathrm{nM}$ affinity for the $\mathrm{A}_{3} \mathrm{AR}$ while compound 16 had a $14 \mathrm{nM}$ affinity for this receptor. Interestingly, 16 displayed at least a 10-fold selectivity, and compound 17 displayed over a 100 fold selectivity for the $A_{3} A R$ in comparison to the $A_{1}$ and $A_{2 A}$ ARs (Figure 4). Compound 17 was also 100 fold selective for the $A_{3} A R$ in comparison to $A_{1} A R$ in assays of adenylate cylase inhibition with an $\mathrm{EC}_{50}$ value of $1.6 \mathrm{nM}$ at the $\mathrm{A}_{3} \mathrm{AR}$ (Figure 5). However, in this assay, 16 was only 8 fold more potent at the $A_{3} A R$ than at the $A_{1} A R$. In GTP $\gamma S$ studies, 16 was 15 fold less potent at the $A_{1} A R$ than in an assay measuring the suppression of cAMP production; however, 17 had similar potency at both $\mathrm{A}_{1} \mathrm{AR}$ 
Table 2: Functional $E C_{50}$ values for nucleoside monomers and dendrimer conjugates to activate the $A_{1} A R\left(\left[{ }^{35} S\right] G T P \gamma S\right.$ binding and cAMP inhibition) and $A_{3}$ AR (cAMP inhibition). ${ }^{a}$

\begin{tabular}{|c|c|c|c|}
\hline Compound & $\frac{\mathbf{A}_{1}}{\left(\left[{ }^{35} \mathrm{~S}\right] \mathrm{GTP} \gamma \mathrm{S} \text { binding), } \mathrm{EC}_{50}(\mathrm{nM})\right.}$ & $\begin{array}{c}\mathbf{A}_{1} \\
\text { (adenylyl cyclase), } \mathrm{EC}_{50}(\mathrm{nM})\end{array}$ & $\begin{array}{c}\mathbf{A}_{3} \\
\text { (adenylyl cyclase), } \mathrm{EC}_{50}(\mathrm{nM})\end{array}$ \\
\hline \multicolumn{4}{|c|}{ Nucleoside Monomers } \\
\hline $\mathbf{I}$ & $94 \pm 26$ & $400 \pm 80$ & $100 \pm 50$ \\
\hline 4 & $1300 \pm 400$ & $350 \pm 20$ & $140 \pm 70$ \\
\hline 7 & $63 \pm 14$ & $89 \pm 17$ & $36 \pm 13$ \\
\hline \multicolumn{4}{|c|}{ Dendrimer Derivatives } \\
\hline I I & $50 \%$ b & inactive ${ }^{c}$ & inactive $^{c}$ \\
\hline 12 & $190 \pm 70$ & $23 \pm 10$ & $25 \pm 10$ \\
\hline 13 & $940 \pm 70$ & $54 \pm 20$ & $17 \pm 2$ \\
\hline 15 & $<10 \%$ b & inactive $^{c}$ & inactive ${ }^{c}$ \\
\hline 16 & $2400 \pm 1300$ & $120 \pm 1$ & $14 \pm 5$ \\
\hline 17 & $370 \pm 190$ & $260 \pm 90$ & $1.6 \pm 0.4$ \\
\hline
\end{tabular}

a. All experiments were performed using adherent $\mathrm{CHO}$ cells stably expressing the $\mathrm{A}_{1}$ or $\mathrm{A}_{3} \mathrm{AR}$. Binding of $\left.{ }^{35} \mathrm{~S}\right] \mathrm{GTP} \gamma \mathrm{S}$ and assays using a cAMP kit were carried out as described in methods. Values are expressed as $E_{50}$ values (mean $\pm S E M, n=3$ ) or as displacement of the radioligand at $10 \mu M$. b. Percent of $\left.{ }^{35} \mathrm{~S}\right] \mathrm{GTP} \gamma \mathrm{S}$ binding at $10 \mu \mathrm{M}$ compared to full agonist. c. Compound produced less than $20 \%$ of total inhibition at $10 \mu \mathrm{M}$ as seen by ADAC.

functional assays, and both compounds were full agonists in both assays. In the GTP $\gamma \mathrm{S}$ study, DPCPX, an $\mathrm{A}_{1}$ antagonist, was able to fully inhibit the binding of [ ${ }^{35}$ S]GTP $\gamma S$ when incubated with 17 (Figure 6), showing that the binding is due to the specific interaction of 17 with the $A_{1}$ receptor. The control dendrimer 15 showed no binding or activity in either cAMP or GTP $\gamma \mathrm{S}$ assays of $\mathrm{A}_{1}$ AR activation. The stably transfected $\mathrm{CHO} \mathrm{A}_{1}$ and $\mathrm{A}_{3}$ cells had $\mathrm{B}_{\max }$ values of $530 \pm 210 \mathrm{fmol} / \mathrm{mg}$ protein and $253 \pm 19 \mathrm{fmol} /$ mg protein, respectively, showing that there is similar receptor expression in both cell lines.

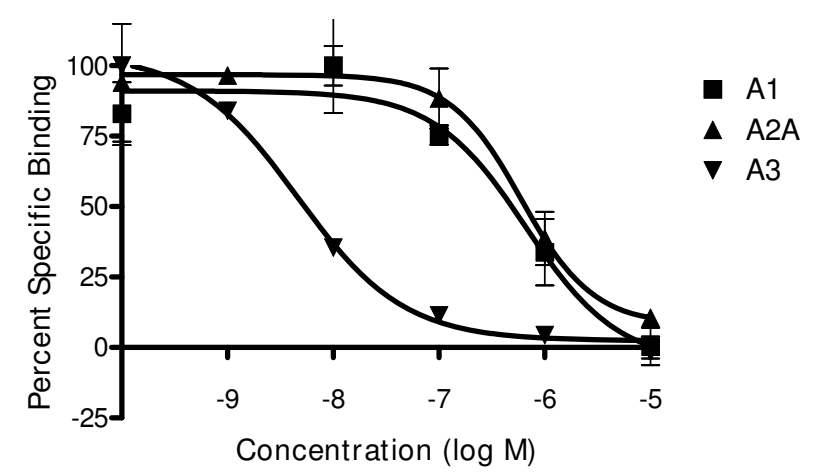

Figure 4

Radioligand binding curves for I7. Increasing concentrations of $\mathbf{I} 7$ were incubated with the appropriate radioligand $\left(A_{1}:\left[{ }^{3} \mathrm{H}\right]\right.$ CCPA, $A_{2 A}:\left[{ }^{3} \mathrm{H}\right]$ CGS2 I680, $A_{3}:\left[{ }^{125} \mid\right]$ l-AB-MECA) and a suspension of $C H O$ cell membranes $\left(A_{1}\right.$ or $\left.A_{3}\right)$ or HEK cells $\left(A_{2 A}\right)$ expressing the appropriate receptor. For a summary of $\mathrm{K}_{\mathrm{i}}$ values obtained, see Table I.

\section{Fluorescent Detection of Dendrimer (G2.5) Conjugates Bound to $A_{3} A R$ Expressed in CHO Cells}

$10 \mu \mathrm{M}$ of compounds 15 or 17 were incubated for $1 \mathrm{~h}$ with $\mathrm{CHO}$ cells that did or did not stably express the $\mathrm{A}_{3}$ AR. After one wash with PBS, the cells were imaged at $100 \times$ magnification on a Zeiss AxioVision D1 Imager, and both light and fluorescent pictures were obtained. As shown in Figure 7, only the cells expressing the $A_{3}$ AR were bound by 17 . Neither type of $\mathrm{CHO}$ cells were bound by 15 , the control dendrimer with no ligand attached. 17 was

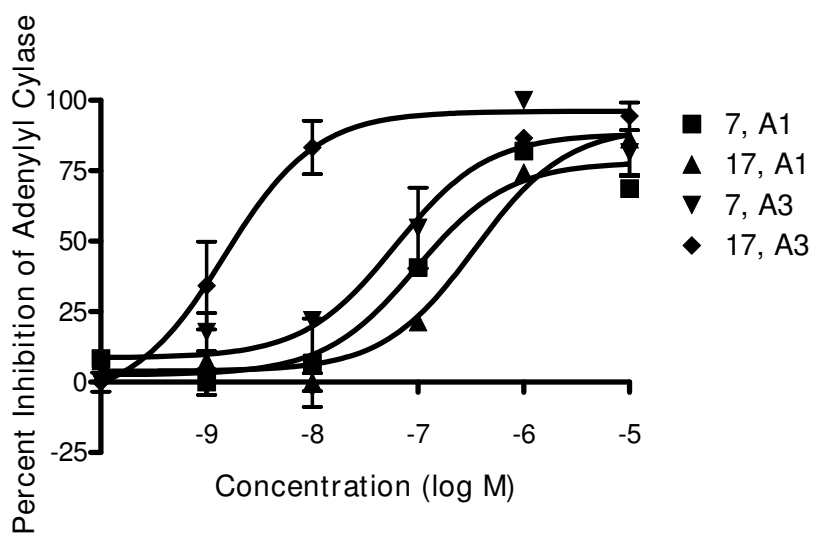

Figure 5

CAMP inhibition curves for 7 and 17. After 30 min incubation with increasing concentrations of $\mathbf{7}$ or $\mathbf{1 7}$, forskolin was added to $\mathrm{CHO}$ cells expressing $\mathrm{A}_{1}$ or $\mathrm{A}_{3} \mathrm{ARs}$ to increase adenylyl cylase. The inhibition of adenylyl cylase was measured using the Direct cAMP Enzyme Immunoassay. For a summary of $E_{50}$ values obtained, see Table 2. The results shown are means \pm S.E.M. of three independent experiments. 


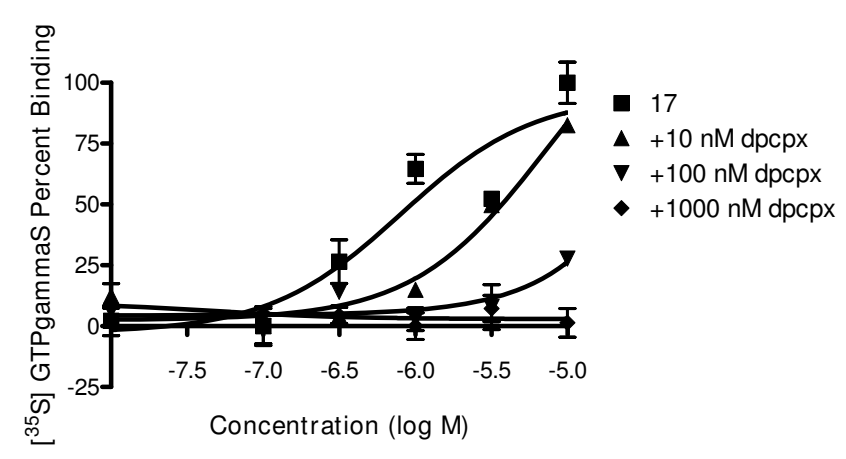

Figure 6

Antagonism by an $A_{1} A R$ antagonist of $\left[{ }^{35}\right.$ S] GTP $\gamma$ S binding induced by compound I7. Compound 17 was incubated with increasing concentrations of $A_{1}$ antagonist DPCPX, [ $\left.{ }^{35} \mathrm{~S}\right] \mathrm{GTP} \gamma \mathrm{S}$, and a $\mathrm{CHO} \mathrm{A}_{1}$ membrane suspension. The amount of [ $\left.{ }^{35} \mathrm{~S}\right] \mathrm{GTP} \gamma \mathrm{S}$ bound was measured, and the results were interpreted with Prism software. The results shown are means \pm S.E.M. of three independent experiments.

unable to bind $\mathrm{CHO}$ cells that did not express the $\mathrm{A}_{3} \mathrm{AR}$. While background fluorescence was seen for both compounds 15 and 17 when incubated with the CHO cells, this fluorescence did not correspond to the location of the cells. The fluorescence bound to the surface of the $A_{3} A R-$ expressing cells was not evenly distributed, but rather showed a punctuated distribution, possibly due to receptor aggregation.

\section{Discussion}

Many drugs have already been delivered using dendrimers by bioreversible covalent conjugation, including methotrexate [25] and penicillin V [26]. Methotrexate, which was covalently attached via a hydrolyzable ester bond to a generation 5 (G5) PAMAM dendrimer that also contained folic acid, was significantly more toxic to folic acid receptor-expressing cancer cells than was the free ligand. The dendrimer with the ligand and folic acid attached and monomeric folic acid appeared to have a similar affinity for the folic acid receptor [25]. Our study differs from the bioreversible approach in that it describes covalent nucleoside-dendrimer conjugates that do not require cleavage in order to achieve a biological effect. It extends previous studies in which another receptor subtype, the $A_{2 A} A R$, was targeted [4,24].

The previous studies of $\mathrm{A}_{2 \mathrm{~A}}$ AR-directed dendrimers utilized exclusively amino-terminal dendrimers, such as G3 PAMAM dendrimers. Dendrimers with free amino groups at the periphery typically display a toxicity that is dependent on both size (i.e. generation) and concentration. This toxicity can be ameliorated by using neutral or anionic dendrimers, such as half-generation PAMAM dendrimers that have terminal carboxyl groups [21]. For instance, G3 PAMAM dendrimers caused significant haemolysis at 4 $\mathrm{mg} / \mathrm{ml}$ in red blood cells, whereas G2.5 PAMAM did not cause haemolysis at $10 \mathrm{mg} / \mathrm{ml}$ [27]. In fact, only G7.5 PAMAM and higher generations caused significant haemolysis at $4 \mathrm{mg} / \mathrm{ml}$. Therefore, we have included in this study dendrimers of half-generation, e.g. 2.5, which have terminal carboxylate groups and are therefore likely to be less toxic. When the G3 dendrimer was used in the present study, most of the amino groups were blocked to avoid cytotoxicity.

The differences between half-generation compared to integral generation PAMAM dendrimers in drug delivery have not been adequately studied. One study did attach methotrexate to G2.5 and G3 dendrimers using the terminal amine and carboxyl groups of the ligand, respectively, and the G2.5 conjugate had increased drug activity compared to either free methotrexate or the G3 conjugate [28]. However, the major reason given for the increased activity with the G2.5 derivative was that the methotrexate was released from the dendrimer due to prolonged interactions with proteases in the lysosome since the G2.5 derivative has an anionic charge. The paper concluded that it was probably necessary for the drug to be released from the dendrimer in order to retain its cytotoxic activity. However, GPCR ligands activate their receptors from outside of the cell, and it is unlikely that the ligand will need to be released from the dendrimer to retain activity. Therefore, there must be a different explanation for the improvement of selectivity and affinity of the G2.5 dendrimer-ligand conjugates.

The two functionalized congeners related to ADAC as well as ADAC itself were attached to the dendrimer through a terminal side chain attached to the same position on the nucleoside and which should not interfere with the binding of the adenosine moiety to the receptor. Each of the nucleoside monomers (compounds 1, 4, and 7) showed less than a 5 fold difference in affinity between the human $A_{1}$ and $A_{3}$ ARs, but 17 had an enhanced affinity and selectivity at $\mathrm{A}_{3} \mathrm{AR}$ in both radioligand binding and cAMP assays. This enhancement can be explained by the difference in the linking moieties, such that the G2.5 dendrimer-ligand conjugates 16 and 17 allow a significant increase in selectivity towards the $A_{3}$ AR compared to the $A_{1}$ AR. This selectivity was not seen with the G3 dendrimer-ligand conjugates, which were approximately equipotent at the $A_{1}$ and $A_{3}$ ARs in both radioligand binding and CAMP assays. However, the decrease in affinity at the $A_{1} A R$ and increase in affinity at $A_{3} A R$ was seen in our previous work using $A_{2 A}$ AR-directed G3 dendrimer-ligand conjugates. This work showed that dendrimer-nucleoside conjugates increased the selectivity at the $A_{2 A} A R$ com- 


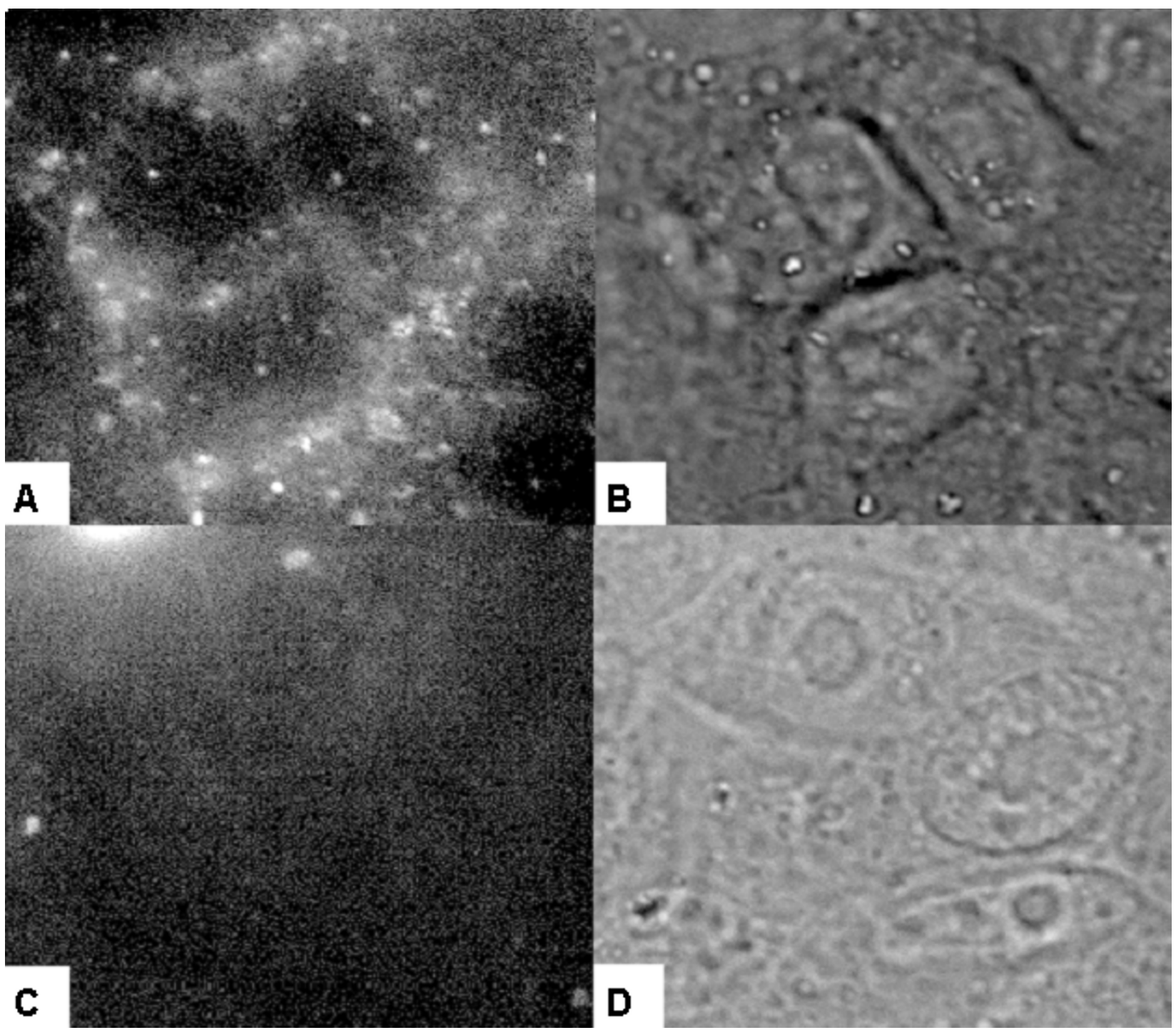

Figure 7

Light and fluorescent microscopy of $\mathbf{C H O}$ or $\mathbf{C H O} \mathbf{A}_{3}$ cells with compound I 7 . The cells were plated $24 \mathrm{~h}$ prior to the experiment. The cells were incubated for I $\mathrm{h}$ with the $10 \mu \mathrm{M}$ of the appropriate compound and imaged with light and fluorescent microscopy. A. CHO $A_{3}$ cells, fluorescent image; $\mathrm{B}$. $\mathrm{CHO} \mathrm{A}_{3}$ cells, light image; $\mathrm{C}$. $\mathrm{CHO}$ cells, fluorescent image; $\mathrm{D}$. $\mathrm{CHO}$ cells, light image.

pared to the $A_{1} A R$ by decreasing the binding affinity at the $A_{1}$ receptor, and that all of the dendrimer ligand-conjugates were most potent at the $A_{3} A R$ [24]. Dendrimer-conjugates 12 and 13, which are approximately equipotent at $A_{1}$ and $A_{3}$ ARs could be useful for cardioprotection [29], while $\mathrm{A}_{3} \mathrm{AR}$ selective conjugates 16 and 17 could be useful in the treatment of rheumatoid arthritis [30].

Since residual amino groups on dendrimers are associated with cytotoxicity, the unreacted terminal positions of the $\mathrm{A}_{3}$ AR-selective G2.5 dendrimer 17 were present as carbox- ylate groups, which had the further benefit of increasing water-solubility. Interestingly, not only does the $\mathrm{A}_{3} \mathrm{AR}$ selectivity of 17 improve upon conjugation to the dendrimer, but the affinity also slightly improves compared to the parent nucleoside, 7 . While this could be due to the fact that the nucleoside concentration is higher since there are multiple ligands attached per dendrimer, it is unlikely that this is the sole cause of the phenomenon. There are only on average three ligands attached per dendrimer, so it is unlikely that all of them are in the correct geometry to bind multiple receptor proteins in the membrane simulta- 
neously. It is possible that the dendrimer-ligand conjugate would be blocking other receptor binding sites for the radioligand since it is much larger than the monomer. However, if this was the case, it would be expected that each of the dendrimer-ligand conjugates is more potent than the free nucleosides; instead, the conjugate $\mathbf{1 6}$ is approximately equipotent to 1 . It could also be possible that due to the overexpression of the $\mathrm{A}_{3} \mathrm{AR}$ on the $\mathrm{CHO}$ cells, $A_{3}$ AR dimers are forming and the dendrimer conjugate is able to bridge the binding sites of both receptors. $\mathrm{A}_{3}$ ARs are known to accumulate in membrane microdomains and may form $A_{3} A R$ homodimers [31]. If there is only one $\mathrm{G}$ protein associated with the GPCR dimer, the receptor that is not attached to the $G$ protein could act as an anchor for the dendrimer ligand complex, allowing for a lowering of the $\mathrm{EC}_{50}$ and $\mathrm{K}_{\mathrm{i} \text { app }}$ values. Previously molecular modeling work at the $\mathrm{A}_{2 \mathrm{~A}} \mathrm{AR}$ has shown that one dendrimer with multiple ligands could bridge an AR dimer [32]. However, further studies are necessary to elucidate the mechanism for the improvement of selectivity and potency of 17 in comparison to 7 .

Compound 17 was also studied using fluorescent microscopy. Interestingly, 17, but not 15 , the control dendrimer with no ligand attached, was able to bind $\mathrm{CHO}$ cells expressing the $\mathrm{A}_{3} \mathrm{AR}$. Neither compound significantly bound to cells that were not expressing the $\mathrm{A}_{3} \mathrm{AR}$. The fluorescence remained associated with the cells expressing the $A_{3} A R$ after washing. Compound 17 appeared to bind some areas of the membrane more strongly than other areas as shown by increase in fluorescent signal. This finding could provide evidence that the $\mathrm{A}_{3} \mathrm{AR}$ is condensed into patches on the cell membrane, possibly as dimers or oligomers. The uneven distribution of the fluorescent signal might indicate the existence of higher-order receptor oligomers, as it been recently demonstrated for the $\mathrm{A}_{2 \mathrm{~A}} \mathrm{AR}$ [33]. We did not use transmission electron microscopy to determine if the fluorescent dendrimer conjugate was internalized by the cells. Internalization of other GPCRs under similar conditions, i.e., incubation with agonist for $1 \mathrm{hr}$ at $37^{\circ} \mathrm{C}$, is established. These two issues might be responsible of the punctuate distribution of $\mathrm{A}_{3}$ ARdependent binding of 17 .

Compounds 12 and 13 are identical, except that 13 contains an additional five ADAC moieties per dendrimer. Interestingly, attaching additional ADAC moieties to G3 PAMAM appeared to cause a slight decrease in affinity at all three ARs, although the selectivity remained similar. Our previous results comparing increasing numbers of $A_{2 A} A R$ ligand attachments to dendrimers also failed to show a significant improvement in affinity by adding multiple ligands to the dendrimer [24]. However, in both of these studies, attaching the monomer to the dendrimer did not create a significant enhancement in affinity, unlike in our new G2.5 conjugates. Therefore, it will be interesting to determine if there is an enhancement in affinity when increasing numbers of ADAC moieties are attached to the G2.5 dendrimers.

\section{Conclusion}

In conclusion, it is feasible to modulate and even enhance the pharmacological profile of a ligand of a GPCR based on conjugation to a nanocarrier and the precise structure of the linking group, which was designed to interact with distal extracellular regions of a 7 transmembrane-spanning receptor. We have demonstrated the feasibility of potent and selective activation of specific subtypes of ARs using multivalent conjugates and the ability to modulate the selectivity based on the linkage between the pharmacophore and the polymeric carrier. Both G2.5 and G3 PAMAM dendrimers can be successfully used in covalent dendrimer-ligand conjugates directed to GPCRs. High selectivity in binding at the $A_{3} A R$ in comparison to the monomeric nucleosides could be achieved, depending on the nature of the linker moiety, i.e., a secondary amine linkage resulted in greater than 100 -fold $\mathrm{A}_{3}$ AR selectivity. The selective macromolecular agonist 17 can now be used in pharmacological models of tissue rescue from ischemia and as a fluorescent ligand tool to characterize the $\mathrm{A}_{3} \mathrm{AR}$ in situ and to probe the existence of $\mathrm{A}_{3} \mathrm{AR}$ dimers. Further studies will be completed using higher generation dendrimers and with new covalently-bound AR ligands. Other GPCRs may also be amenable to this approach to the design of multivalent ligands.

\section{Methods \\ Materials}

ADAC, PAMAM dendrimers (ethylenediamine core, generations 2.5 as $10 \mathrm{wt}$. \% solution in methanol and generations 3 as $20 \mathrm{wt}$. \% solution in methanol solution), 3-(4aminophenyl)propionic acid, (benzotriazol-1yloxy)tripyrrolidinophosphonium hexafluorophos-phate (PyBOP), 3-[(3-cholamidopropyl)dimethyl-ammonio]1-propanesulfonate hydrate (CHAPS), adenosine deaminase, bovine serum albumin, sodium borate, guanosine 5'-diphosphate sodium salt (GDP), $\mathrm{N}$-(3-dimethylaminopropyl)-N'-ethylcarbodiimide (EDC), dithiothreitol, ethylene-diaminetetraacetic acid acetic anhydride (EDTA), 2( $N$-morpholino)ethanesulfonic acid (MES), magnesium chloride, sodium chloride, methanol, thiophosgene, triethylamine, diethyl ether, methyl sulfoxide- $\mathrm{d}_{6}$ (DMSO$\mathrm{d}_{6}$ ), and $N, N$-dimethylformamide (DMF) were purchased from Sigma (St. Louis, MO). Bio-Beads ${ }^{\circledast}$ SX-1 beads were purchased from Bio-Rad (Hercules, CA). Alexa-Fluor ${ }^{\circledast} 488$ carboxylic acid, 2,3,5,6-tetrafluorophenyl ester, 5-isomer (AF488-TFP) was purchased from Invitrogen (Carlsbad, CA). [ ${ }^{125}$ I]-4-Amino-3-iodobenzyl-5'-N-methylcarboxamidoadenosine ([125I]AB-MECA, $2200 \mathrm{Ci} / \mathrm{mmol}),\left[{ }^{3} \mathrm{H}\right]-2-$ chloro- $\mathrm{N}^{6}$-cyclopentyladenosine $\left(\left[{ }^{3} \mathrm{H}\right] \mathrm{CCPA}, 42.6 \mathrm{Ci} /\right.$ 
$\mathrm{mmol})$, and $\left[{ }^{3} \mathrm{H}\right]-2-[\mathrm{p}-(2$-carboxyethyl)phenylethylamino]-5'-N-ethylcarboxamidoadenosine

([ $\left.\left.{ }^{3} \mathrm{H}\right] \mathrm{CGS} 21680,40.5 \mathrm{Ci} / \mathrm{mmol}\right)$ were purchased from Perkin Elmer (Waltham, MA). [ ${ }^{35}$ S]GTP $\gamma \mathrm{S}$ (1133 Ci/ $\mathrm{mmol}$ ) was purchased from GE Healthcare (Buckinghamshire, England). DMEM/F12 medium and $1 \mathrm{M}$ Tris-HCl ( $\mathrm{pH}$ 7.5) were purchased from Mediatech, Inc. (Herndon, VA).

\section{Chromatography and spectroscopy}

To prepare a column for size exclusion chromatography (SEC), $100 \mathrm{~g}$ of Bio-Beads ${ }^{\circledR}$ SX-1 beads were suspended in $1 \mathrm{~L}$ of DMF. After $24 \mathrm{~h}$ to allow for equilibration and expansion, the beads were added to the column as described previously [21]. High Performance Liquid Chromatography (HPLC) purification was performed using an Agilent 1100 Series HPLC (Santa Clara, CA) equipped with a Phenomenex Luna $5 \mu \mathrm{C} 18(2) 100 \mathrm{~A}$ analytical column $(250 \times 10 \mathrm{~mm}$; Torrance, CA $)$. Peaks were detected by UV absorption using a diode array detector. Proton nuclear magnetic resonance spectra (NMR) were recorded on a Bruker DRX-600 spectrometer after being optimized for each sample using DMSO- $\mathrm{d}_{6}$ as a solvent unless otherwise noted. To determine the number of ligands attached to each dendrimer, the integration of NMR resonances of the ligand was compared to the integration of signal from one of the sets of carbon-protons on the interior of the dendrimer as described previously [4]. Electrospray ionization mass spectra (ESI MS) were taken using a Waters LCT Premier mass spectrometer. Matrix Assisted Laser Desorption/Ionization Time-of-Flight (MALDI-TOF) spectra were obtained with a Waters Micro mass spectrometer using Waters MassPREP Direct Ionization on Silica Desorption/ionization (DIOS) target plates.

The ESI MS data for the dendrimer complexes was obtained using a Waters LCT Premier TOF mass spectrometer. The mass spectrometer was operated in positive ion $\mathrm{W}$ mode with a resolution of 10000 measured at half peak height. The capillary voltage was 2500 volts, the cone voltage was 40 volts, and the desolvation gas was dried nitrogen at $250^{\circ} \mathrm{C}$ and a flow of $300 \mathrm{~L} / \mathrm{h}$. The sample was dissolved in a $1: 1$ solution of water:acetonitrile containing $0.2 \%$ formic acid and injected directly into the eluting stream flowing at $200 \mu \mathrm{L} / \mathrm{min}$ and consisting of 20:80 water:acetonitrile and $0.2 \%$ formic acid. The relevant spectra were summed using the MassLynx software, and the summed spectrum was deconvoluted with the MaxEntI program.

Chemical synthesis - 3-(4-Thiocarbamoylphenyl)propanoic acid (3) 3-(4-Aminophenyl)propanoic acid (2) (100 mg, 670 $\mu \mathrm{mol})$ was dissolved in $0.7 \mathrm{~mL}$ of $0.8 \mathrm{M}$ aqueous $\mathrm{KOH}$. Thiophosgene $(51.1 \mu \mathrm{L}, 670 \mu \mathrm{mol})$ was diluted with 1.2 mL of water. The 3-(4-aminophenyl)propanoic acid solu- tion was added dropwise to the freshly prepared thiophosgene solution. A solid immediately precipitated and redissolved upon the addition of $4.2 \mathrm{~mL}$ water. After $1 \mathrm{~h}$, the solution was vacuum-filtered and vacuum-dried overnight to give $98.6 \mathrm{mg}$ of 3-(4-thiocarbamoylphenyl)propanoic acid $(475 \mu \mathrm{mol}, 80 \%$ yield $) .{ }^{1} \mathrm{H}$ NMR $\left(\mathrm{CDCl}_{3}\right)$ 7.27-7.30 (m, $2 \mathrm{H}), 7.15-7.23(\mathrm{~m}, 2 \mathrm{H}), 2.93(\mathrm{t}, \mathrm{J}=7.9$ $\mathrm{Hz}, 2 \mathrm{H}), 2.68(\mathrm{t}, \mathrm{J}=7.4 \mathrm{~Hz}, 2 \mathrm{H}) \mathrm{m} / z\left(\mathrm{M}^{+} \mathrm{ESI} M S\right)$ calc: 208.0432 found: 208.0423 .

3-(4-(3-(2--2-(4-(2-(4-(9-((2R,3R,4S,5R)-3,4-Dihydroxy-5(hydroxymethyl)tetrahydrofuran-2-yl)-9H-purin-6-

ylamino)phenyl)acetamido)-

phenyl)acetamido)ethyl)thioureido)phenyl)pro-panoic acid (4)

3-(4-Thiocarbamoylphenyl)propanoic acid (3) (12 mg, $60.7 \mu \mathrm{mol})$ and ADAC (1) $(35 \mathrm{mg}, 60.7 \mu \mathrm{mol})$ were dissolved in $4 \mathrm{ml}$ of DMF. Triethylamine $(20 \mu \mathrm{L}, 143 \mu \mathrm{mol})$ was added, and the reaction was stirred for $1 \mathrm{~h}$. The DMF was removed under nitrogen and the resulting oil was dissolved in methanol. Ether was added to precipitate the product. After removal of the supernatant and drying, the resulting product $(17.8 \mathrm{mg}, 22.8 \mu \mathrm{mol}, 37 \%$ yield $)$ was judged homogenous by TLC. ${ }^{1} \mathrm{H}$ NMR (DMSO- $\left.\mathrm{d}_{6}\right) 10.10$ (s, 1H), $9.93(\mathrm{~s}, 1 \mathrm{H}), 9.52(\mathrm{br} \mathrm{s}, 1 \mathrm{H}), 8.53(\mathrm{~s}, 1 \mathrm{H}), 8.37$ (s, $1 \mathrm{H}), 8.10(\mathrm{t}, \mathrm{J}=6.1 \mathrm{~Hz}, 1 \mathrm{H}), 7.85(\mathrm{~d}, \mathrm{~J}=8.9 \mathrm{~Hz}, 2 \mathrm{H}), 7.66$ (br s, $1 \mathrm{H}), 7.52(\mathrm{~d}, \mathrm{~J}=8.5,2 \mathrm{H}), 7.21-7.33(\mathrm{~m}, 4 \mathrm{H})$, 7.13-7.20 (m, 4H), $5.95(\mathrm{~d}, \mathrm{~J}=6.0 \mathrm{~Hz}, 1 \mathrm{H}), 5.48(\mathrm{~d}, \mathrm{~J}=$ $5.5,1 \mathrm{H}), 5.29(\mathrm{t}, \mathrm{J}=5.6 \mathrm{~Hz}, 1 \mathrm{H}), 5.21(\mathrm{~d}, \mathrm{~J}=4.6 \mathrm{~Hz}, 1 \mathrm{H})$, $4.63(\mathrm{~m}, 1 \mathrm{H}), 4.17(\mathrm{~m}, 1 \mathrm{H}), 3.98(\mathrm{dd}, \mathrm{J}=3.6,4.0 \mathrm{~Hz}, 1 \mathrm{H})$, $3.65-3.74(\mathrm{~m}, 1 \mathrm{H}), 3.59(\mathrm{~s}, 1 \mathrm{H}), 3.53(\mathrm{~m}, 2 \mathrm{H}), 3.20-3.29$ $(\mathrm{m}, 2 \mathrm{H}), 2.72-2.83(\mathrm{~m}, 2 \mathrm{H}) \mathrm{m} / \mathrm{z}\left(\mathrm{M}^{+}\right.$ESI MS $)$calc: 784.2877 found: 784.2882 .

N-(2-(2-Aminoethylamino)ethyl)-2-(4-(2-(4-(9-((2R,3R,4S,5R)-3,4dihydroxy-5-(hydroxymethyl)-tetrahydrofuran-2-yl)-9H-purin-6ylamino)-phenyl)acetamido)phenyl)acetamide (7)

This compound was synthesized according to a similar procedure to obtain ADAC (17). $N^{6}-[4-[[[4-((2-m e t h o x y)-$ 2-oxyethyl)anilino]carbonyl]-methyl]-phenyl]adenosine (5) $(4.97 \mathrm{mg}, 9.1 \mu \mathrm{mol})$ was dissolved in $1 \mathrm{~mL}$ of DMF, and diethylenetriamine (6) $(150 \mu \mathrm{L}, 1.37 \mathrm{mmol})$ was added to this solution. The reaction was stirred overnight under nitrogen, and the DMF was removed under a stream of dry nitrogen. The resulting oil was dissolved in methanol, and a solid was precipitated upon addition of ether. After removal of the supernatant, the remaining solid was dried overnight to give $3.75 \mathrm{mg}$ of product $(6.05 \mu \mathrm{mol}$, $66.5 \%$ yield). ${ }^{1} \mathrm{H}$ NMR (DMSO- $\left.\mathrm{d}_{6}\right) 10.11(\mathrm{~s}, 1 \mathrm{H}), 9.94(\mathrm{br}$ $\mathrm{s}, 1 \mathrm{H}) 8.53(\mathrm{~s}, 1 \mathrm{H}), 8.38(\mathrm{~s}, 1 \mathrm{H}), 7.90-8.04(\mathrm{~m}, 2 \mathrm{H}), 7.84$ $(\mathrm{d}, \mathrm{J}=9.0 \mathrm{~Hz}, 2 \mathrm{H}), 7.51(\mathrm{~d}, \mathrm{~J}=7.6 \mathrm{~Hz}, 2 \mathrm{H}), 7.29(\mathrm{~d}, \mathrm{~J}=$ $8.4 \mathrm{~Hz}, 2 \mathrm{H}), 7.18(\mathrm{~d}, \mathrm{~J}=8.8 \mathrm{~Hz}, 2 \mathrm{H}), 5.95(\mathrm{~d}, \mathrm{~J}=6.9 \mathrm{~Hz}$, 1H) $5.32(\mathrm{~m}, 1 \mathrm{H}), 4.63(\mathrm{t}, \mathrm{J}=5.7 \mathrm{~Hz}, 1 \mathrm{H}), 4.17(\mathrm{t}, \mathrm{J}=4.8$ $\mathrm{Hz}, 1 \mathrm{H}), 3.98(\mathrm{dd}, \mathrm{J}=3.4 \mathrm{~Hz}, 2.1 \mathrm{~Hz}, 1 \mathrm{H}), 3.59(\mathrm{~m}, 3 \mathrm{H})$, 3.10-3.15 (m, 4H), $2.62(\mathrm{~m}, 2 \mathrm{H}), 2.55(\mathrm{~s}, 6 \mathrm{H}, 21,22)$, 
$1.10 \mathrm{p}(\mathrm{t}, \mathrm{J}=6.8 \mathrm{~Hz}, 3 \mathrm{H}) . \mathrm{m} / \mathrm{z}$ (M+ ESI MS) calc: 620.2945 found: 620.2931 .

2-(6-Amino-3-iminio-4,5-disulfonato-3H-xanthen-9-yl)-5-(2aminoethylcarbamoyl)benzoate (I 4)

$5 \mathrm{mg}$ of AF488-TFP (10) $(5.65 \mu \mathrm{mol})$ was dissolved in 280 $\mu \mathrm{L}$ of DMF. In order to provide a basic environment, 1.50 mL of $0.1 \mathrm{M} \mathrm{NaB}_{4} \mathrm{O}_{7}, \mathrm{pH} 8.5$ was added. $10 \mu \mathrm{L}$ of ethylenediamine diluted with $210 \mu \mathrm{L}$ of water was added, and the mixture was stirred overnight. The product was purified by HPLC using the following water/acetonitrile linear gradient: 0 min, $0 \%$ acetonitrile; $25 \mathrm{~min}, 100 \%$ acetonitrile. The product eluted at $10.8 \mathrm{~min}$. After lyophilization, 3.02 mg of product $(5.2 \mu \mathrm{mol})$ remained (93\% yield). ${ }^{1} \mathrm{H}$ NMR $\left(\mathrm{D}_{2} \mathrm{O}\right) 8.33(\mathrm{~d}, \mathrm{~J}=2.3 \mathrm{~Hz}, 1 \mathrm{H}), 8.17(\mathrm{t}, \mathrm{J}=1.9 \mathrm{~Hz}, 1 \mathrm{H})$, $7.90(\mathrm{~m}, 1 \mathrm{H}), 7.24(\mathrm{t}, \mathrm{J}=7.5,1 \mathrm{H}), 7.16(\mathrm{dd}, \mathrm{J}=7.5,1.9$, $1 \mathrm{H}), 7.08(\mathrm{~d}, \mathrm{~J}=9.6,2 \mathrm{H}), 6.83(\mathrm{t}, \mathrm{J}=8.8,4 \mathrm{H}), 3.63(\mathrm{~m}$, $1 \mathrm{H}), 3.51(\mathrm{t}, \mathrm{J}=11.7,2 \mathrm{H}), 3.40(\mathrm{t}, \mathrm{J}=5.0,2 \mathrm{H}), 3.13-3.21$ $(\mathrm{m}, 2 \mathrm{H}) \mathrm{m} / \mathrm{z}\left(\mathrm{M}^{-} \mathrm{Na}\right.$ MALDI-TOF MS) calc: 597.0362 found: 597.0383 .

\section{G3 PAMAM - 23 Ac - AF488 (I I) - Method I}

$1 \mathrm{~mL}$ of G3 PAMAM methanol stock solution $(18.8 \mathrm{mM}$, $18.8 \mu \mathrm{mol}$, Sigma) was added to a flask, and the methanol was evaporated. The remaining polymer was dissolved in $1 \mathrm{~mL}$ of DMSO-d ${ }_{6}$. Acetic anhydride $(40.8 \mu \mathrm{L}, 432 \mu \mathrm{mol}$, $23 \mathrm{eq}$ ) was diluted in $1 \mathrm{~mL}$ of DMSO- $\mathrm{d}_{6}$, and this solution was added dropwise to the solution of G3 PAMAM while stirring. After $18 \mathrm{~h}$, an NMR spectrum showed approximately 23 acetamide groups per dendrimer, as expected, to give $9.460 \mu \mathrm{l}$ of this solution $(4.32 \mu \mathrm{mol}, 9.4 \mathrm{mM})$ was removed and diluted to $1.46 \mathrm{~mL}$ with DMSO- $\mathrm{d}_{6}$. Triethylamine $(10 \mu \mathrm{L}, 72 \mu \mathrm{mol})$ was added under a nitrogen atmosphere. AF488-TFP (10) (4 mg, $4.52 \mu \mathrm{mol}, 1.05 \mathrm{eq}$ ) was dissolved in $400 \mu \mathrm{L}$ of DMSO- $\mathrm{d}_{6}$ and added to the mixture. After $48 \mathrm{~h}$, the solution was vacuum filtered to remove a small amount orange precipitate that formed. The NMR spectrum was consistent with the assigned structure, but the signals resulting from AF488 could not be properly integrated due to the large G3 PAMAM peaks. The molecular weight of the compound was unable to be determined using either ESI or MALDI-TOF MS. Therefore, it was assumed that approximately one Alexa-Fluor 488 moiety was attached per G3 PAMAM, based on previous data [4].

\section{G3 PAMAM - 23 Ac - AF488 (I I) - Method 2}

$0.5 \mathrm{~mL}$ of G3 PAMAM methanol stock solution $(18.8 \mathrm{mM}$, $9.4 \mu \mathrm{mol})$ was added to a flask, and the methanol was evaporated. The remaining polymer was dissolved in 0.5 mL of DMSO- $\mathrm{d}_{6}$. Acetic anhydride $(20.4 \mu \mathrm{L}, 216 \mu \mathrm{mol}, 23$ eq) was diluted in $0.5 \mathrm{~mL}$ of DMSO- $\mathrm{d}_{6}$, and this solution was added dropwise to the solution of G3 PAMAM with stirring. After $18 \mathrm{~h}$, an NMR spectrum of the reaction mixture showed approximately 23 acetamide groups per den- drimer, as expected, to give 9. $234 \mu \mathrm{L}$ of this solution (2.2 $\mu \mathrm{mol}, 9.4 \mathrm{mM}$ ) was removed and diluted to $500 \mu \mathrm{L}$ with DMSO-d 6 . AF488-TFP (10) ( 2 mg, $2.3 \mu \mathrm{mol}, 1.05 \mathrm{eq})$ was dissolved in $300 \mu \mathrm{L}$ of $0.1 \mathrm{M}$ MES, pH 5 and added to the mixture under nitrogen atmosphere. EDC (42 mg, 220 $\mu \mathrm{mol})$ was dissolved in $300 \mu \mathrm{L}$ of $0.1 \mathrm{M} \mathrm{MES}, \mathrm{pH} 5$ and added to the reaction mixture. After $48 \mathrm{~h}$, the solution was vacuum filtered to remove a small amount orange precipitate that formed. The NMR spectrum was consistent with the assigned structure, but the signals resulting from AF488 could not be properly integrated due to the large G3 PAMAM peaks. The molecular weight of the compound was unable to be determined using either ESI or MALDI-TOF MS. Therefore, it was assumed that approximately one Alexa-Fluor 488 moiety was attached per G3 PAMAM based on previous data [4].

G3 PAMAM - 23 Ac - AF488 (containing 3 moieties of 4) (I 2)

$650 \mu \mathrm{L}$ of 11 prepared by method $2(2.0 \mathrm{mM}$ solution in DMSO- $\left.\mathrm{d}_{6}, 1.3 \mu \mathrm{mol}\right)$ was removed and placed under nitrogen gas. Compound 4 ( $5 \mathrm{mg}, 6.4 \mu \mathrm{mol})$ was dissolved in $600 \mu \mathrm{L}$ of DMSO and added to the mixture under a nitrogen atmosphere. EDC- $\mathrm{HCl}$ (25 mg, 130 $\mu \mathrm{mol})$ was dissolved in $350 \mu \mathrm{L} 0.1 \mathrm{M}$ MES, pH 5 and added to the mixture. After $48 \mathrm{hr}$, the product was purified by extensive dialysis (Specta/Por Membrane, MWCO 3500, flat width $18 \mathrm{~mm}$, Spectrum Laboratories, Inc., Rancho Dominguez, CA) in water. After lyophilization, 5.85 mg remained, which contained on average 3 moieties of 4 per dendrimer $(0.54 \mu \mathrm{mol}, 41 \%$ yield based on $\mu \mathrm{mol}$ of dendrimer). $10.11(\mathrm{~s}, 4 \mathrm{H}), 9.94(\mathrm{~s}, 3 \mathrm{H}), 8.54(\mathrm{~s}, 4 \mathrm{H}), 8.38$ $(\mathrm{s}, 4 \mathrm{H}), 8.00(\mathrm{~s}, 45 \mathrm{H}), 7.92(\mathrm{~s}, 41 \mathrm{H}), 7.85(\mathrm{~s}, 13 \mathrm{H}), 7.51$ (br s, 6H), $7.29(\mathrm{~d}, \mathrm{~J}=7.5,9 \mathrm{H}), 7.17(\mathrm{~m}, 6 \mathrm{H}), 5.96(\mathrm{~d}, \mathrm{~J}=$ $6.1,2 \mathrm{H}), 5.49(\mathrm{~d}, \mathrm{~J}=4.2,2 \mathrm{H}), 5.30(\mathrm{t}, \mathrm{J}=4.8,2 \mathrm{H}), 5.22$ $(\mathrm{m}, 3 \mathrm{H}), 4.63(\mathrm{~m}, 3 \mathrm{H}), 4.18(\mathrm{~m}, 3 \mathrm{H}), 3.98(\mathrm{~m}, 3 \mathrm{H}), 3.33$ $(\mathrm{s}, 226 \mathrm{H}), 3.08(\mathrm{~s}, 203 \mathrm{H}), 2.70(\mathrm{~s}, 124 \mathrm{H}), 2.23(\mathrm{~s}, 120 \mathrm{H})$, $1.80(\mathrm{~s}, 69 \mathrm{H}) . m / z$ (M+ ESI MS) calc: 10865 found: 11068 .

G3 PAMAM - Ac - AF488 AF488 (containing 8 moieties of 4) (I3) $660 \mu \mathrm{L}$ of 11 prepared by method 1 ( $2.3 \mathrm{mM}$ solution in DMSO- $\left.\mathrm{d}_{6}, 1.52 \mu \mathrm{mol}\right)$ was removed and placed under nitrogen gas. Compound $4(11.8 \mathrm{mg}, 15 \mu \mathrm{mol})$ was dissolved in $200 \mu \mathrm{l}$ of DMSO and added to the mixture. Finally, a mixture of triethylamine $(28 \mu \mathrm{L}, 202 \mu \mathrm{mol})$ and PyBOP ( $26 \mathrm{mg}, 50 \mu \mathrm{mol}$ ) dissolved in $1.5 \mathrm{~mL}$ of DMSO was added. After $48 \mathrm{hr}$, the product was purified by SEC using DMF as the eluent. The fractions containing product which had the Alexa-488 moiety were dried and dissolved in DMSO- $\mathrm{d}_{6}$ for NMR. The first and last fractions containing the product were excluded to provide a more homogenous sample. The remaining fractions were combined and dried to give $8.68 \mathrm{mg}$ of product, which contained on average 8 moieties of 4 per dendrimer ( $0.694 \mu \mathrm{mol}, 46 \%$ yield based on $\mu \mathrm{mol}$ of dendrimer). ${ }^{1} \mathrm{H}$ NMR (DMSO- $\mathrm{d}_{6}$ ) $10.11(\mathrm{~s}, 8 \mathrm{H}), 9.94(\mathrm{~s}, 8 \mathrm{H}), 9.53(\mathrm{~s}, 5 \mathrm{H}), 8.54(\mathrm{~s}, 8 \mathrm{H})$, 
$8.38(\mathrm{~s}, 8 \mathrm{H}), 8.10(\mathrm{t}, \mathrm{J}=6.0 \mathrm{~Hz}), 7.96(\mathrm{~s}, 41 \mathrm{H}), 7.90(\mathrm{~s}$, $33 \mathrm{H}), 7.84(\mathrm{~m}, 41 \mathrm{H}), 7.52(\mathrm{~d}, \mathrm{~J}=8.6 \mathrm{~Hz}, 16 \mathrm{H}), 7.24(\mathrm{~d}, \mathrm{~J}$ $=8.3 \mathrm{~Hz}, 16 \mathrm{H}), 7.17(\mathrm{~m}, 34 \mathrm{H}), 5.96(\mathrm{~d}, \mathrm{~J}=6.2,7 \mathrm{H}), 5.50$ (br s, 4H), 5.31 (br s, 7H), 5.22 (br s, 5H), $4.64(\mathrm{t}, \mathrm{J}=4.2$ $\mathrm{Hz}, 8 \mathrm{H}), 4.18(\mathrm{t}, \mathrm{J}=3.4 \mathrm{~Hz}, 8 \mathrm{H}), 3.99(\mathrm{dd}, \mathrm{J}=2.7,3.7$, $8 \mathrm{H}), 3.70(\mathrm{~m}, 11 \mathrm{H}), 3.59(\mathrm{~m}, 44 \mathrm{H}), 3.08(\mathrm{~s}, 176 \mathrm{H}), 2.90$ $(\mathrm{s}, 8 \mathrm{H}), 2.74(\mathrm{~s}, 9 \mathrm{H}), 2.65(\mathrm{~s}, 120 \mathrm{H}), 2.43(\mathrm{~s}, 77 \mathrm{H}), 2.19$ $(\mathrm{s}, 120 \mathrm{H}), 1.80(\mathrm{~s}, 69 \mathrm{H}) \cdot \mathrm{m} / z\left(\mathrm{M}^{+} \mathrm{ESI} \mathrm{MS}\right)$ calc: 14241 found: 14226 .

\section{G2.5 PAMAM - AF488 (15)}

This procedure was adapted from a carbodiimide coupling described previously [19,20]. $5 \mu \mathrm{mol}$ of G2.5 PAMAM stock solution (14.3 mM in methanol, $31.3 \mathrm{mg}$ ) was added to a flask, and the methanol was evaporated. The remaining residue containing the polymer and compound $14(3.0 \mathrm{mg}, 5.2 \mu \mathrm{mol})$ were dissolved in $1.7 \mathrm{~mL}$ of 0.1 M MES buffer, pH 5. EDC $(40.4 \mathrm{~g}, 260 \mu \mathrm{mol})$ dissolved in $1 \mathrm{~mL}$ of $0.1 \mathrm{M}$ MES buffer, $\mathrm{pH} 5$, was added, and the reaction stirred for $60 \mathrm{~h}$. After dialysis with water, the mixture was lyophilized to give $13.4 \mathrm{mg}$ ( $1.97 \mu \mathrm{mol}, 37 \%$ yield) and redissolved in $\mathrm{D}_{2} \mathrm{O}$ for NMR measurements and further biological assays. ${ }^{1} \mathrm{H}$ NMR $\left(\mathrm{D}_{2} \mathrm{O}\right) 8.25$ (s, $1 \mathrm{H}), 7.78-8.10(\mathrm{~m}, 1 \mathrm{H}), 7.53(\mathrm{~s}, 1 \mathrm{H}), 7.32(\mathrm{~s}, 1 \mathrm{H}), 7.10$ $(\mathrm{s}, 1 \mathrm{H}), 6.89(\mathrm{~m}, 1 \mathrm{H}), 3.42(\mathrm{~s}, 26 \mathrm{H}), 3.15(\mathrm{~m}, 90 \mathrm{H}), 2.72$ $(\mathrm{s}, 120 \mathrm{H}), 2.52(\mathrm{~s}, 60 \mathrm{H}), 2.38(\mathrm{~m}, 122 \mathrm{H})$. The molecular weight was unable to be determined using ESI or MALDITOF MS due to stacking of the PAMAM dendrimer.

\section{G2.5 PAMAM - AF488 (containing 3 moieties of I) (I6)}

$620 \mu \mathrm{L}$ of a stock solution of 15 in $\mathrm{D}_{2} \mathrm{O}$ was dried to give $9.32 \mathrm{mg}(1.4 \mu \mathrm{mol})$, which was redissolved in $1 \mathrm{~mL}$ of 0.1 $\mathrm{M}$ MES, pH 5 and placed under a nitrogen atmosphere [20]. ADAC (8.92 mg, $14 \mu \mathrm{mol})$ was dissolved in $600 \mu \mathrm{L}$ of DMSO and was added to the solution of 15. Finally, 27 mg of EDC $(141 \mu \mathrm{mol})$ was dissolved in $500 \mu \mathrm{L}$ of $0.1 \mathrm{M}$ MES, pH 5 and added to the mixture. After approximately $48 \mathrm{~h}$, small molecule impurities were removed by extensive dialysis in water. After lyophilization, $8.06 \mathrm{mg}(0.96$ $\mu \mathrm{mol}, 68 \%$ yield) of product remained. The product was analyzed by NMR, which showed approximately 3 ADAC moieties attached per dendrimer. ${ }^{1} \mathrm{H}$ NMR $\left(D_{M S O}-\mathrm{d}_{6}\right)$ $8.48(\mathrm{~s}, 3 \mathrm{H}), 8.35(\mathrm{~s}, 3 \mathrm{H}), 7.76(\mathrm{~s}, 6 \mathrm{H}), 7.47(\mathrm{~m}, 6 \mathrm{H})$, $7.29(\mathrm{~m}, 6 \mathrm{H}), 7.16(\mathrm{~m} 6 \mathrm{H}), 5.92(\mathrm{~d}, \mathrm{~J}=5.5,3 \mathrm{H}), 4.60(\mathrm{~m}$, $3 \mathrm{H}), 4.16(\mathrm{~m}, 3 \mathrm{H}), 3.99(\mathrm{~m}, 3 \mathrm{H}), 3.56(\mathrm{~s}, 31 \mathrm{H}), 3.07(\mathrm{~s}$, $90 \mathrm{H}), 2.63(\mathrm{~s}, 120 \mathrm{H}), 2.44(\mathrm{~s}, 70 \mathrm{H}), 2.20(\mathrm{~s}, 120 \mathrm{H}) . \mathrm{m} / \mathrm{z}$ (M+ ESI MS) calc: 8405 found: 7811

\section{G2.5 PAMAM - AF488 (containing 3 moieties of 7)(I 7)}

$640 \mu \mathrm{L}$ of a stock solution of 15 in $\mathrm{D}_{2} \mathrm{O}$ was dried to give $10.2 \mathrm{mg}(1.5 \mu \mathrm{mol})$, which was redissolved in $600 \mu \mathrm{L}$ of $0.1 \mathrm{M}$ MES, pH 5 and placed under a nitrogen atmosphere. 7 (9.2 mg, $15 \mu \mathrm{mol})$ was dissolved in $1 \mathrm{~mL}$ of DMSO and was added to 15. Finally, $28 \mathrm{mg}$ of EDC (146 $\mu \mathrm{mol})$ was dissolved in $500 \mu \mathrm{L}$ of $0.1 \mathrm{M}$ MES, pH 5 and added to the mixture. After approximately $48 \mathrm{~h}$, small molecule impurities were removed by extensive dialysis in water. After lyophilization, $9.74 \mathrm{mg}$ (1.14 $\mu \mathrm{mol}, 76 \%$ yield) of product remained. The product was analyzed by NMR, which showed approximately 3 ADAC moieties attached per dendrimer. ${ }^{1} \mathrm{H}$ NMR (DMSO-d ${ }_{6}$ ) 10.20 (s, $2 \mathrm{H}), 9.86(\mathrm{~s}, 2 \mathrm{H}), 8.47(\mathrm{~s}, 2 \mathrm{H}), 8.35(\mathrm{~s}, 2 \mathrm{H}), 7.78-8.30$ (m, 91H), 7.76 (br s, 7H), 7.47 (br s, 6H), 7.29 (br s, 5H), $7.16(\mathrm{br} \mathrm{s}, 6 \mathrm{H}), 5.92(\mathrm{t}, \mathrm{J}=5.7,2 \mathrm{H}), 5.30(\mathrm{~m}, 6 \mathrm{H}), 4.60$ $(\mathrm{m}, 5 \mathrm{H}), 3.54(\mathrm{~s}, 46 \mathrm{H}), 3.10(\mathrm{~s}, 104 \mathrm{H}), 2.98(\mathrm{~m}, 28 \mathrm{H})$, $2.63(\mathrm{~s}, 160 \mathrm{H}), 2.42(\mathrm{~s}, 78 \mathrm{H}), 2.36(\mathrm{~s}, 56 \mathrm{H}), 2.20(\mathrm{~s}$, $120 \mathrm{H})$. The mass spectrum of this compound was too fragmented to determine a molecular weight.

\section{Cell Culture and Membrane Preparation}

$\mathrm{CHO}$ (Chinese hamster ovary) cells stably expressing the recombinant human ARs were cultured in Dulbecco's modified Eagle medium (DMEM) and F12 (1:1) supplemented with $10 \%$ fetal bovine serum, 100 units/mL penicillin, $100 \mu \mathrm{g} / \mathrm{mL}$ streptomycin, and $2 \mu \mathrm{mol} / \mathrm{mL}$ glutamine. After harvesting, cells were homogenized and suspended. Cells were then centrifuged at $500 \mathrm{~g}$ for 10 $\mathrm{min}$, and the pellet was resuspended in $50 \mathrm{mM}$ Tris- $\mathrm{HCl}$ buffer ( $\mathrm{pH} 7.5$ ) containing $10 \mathrm{mM} \mathrm{MgCl}_{2}$. The suspension was homogenized and was then recentrifuged at $20000 \mathrm{~g}$ for $20 \mathrm{~min}$ at $4^{\circ} \mathrm{C}$. The resultant pellets were resuspended in Tris buffer, incubated with adenosine deaminase for 30 $\min$ at $37^{\circ} \mathrm{C}$, and the suspension was stored at $-80^{\circ} \mathrm{C}$ until the binding experiments. The protein concentration was measured using the BCA Protein Assay Kit from Pierce [20].

\section{Radioligand Membrane Binding Studies}

Radioligand binding assays were performed for $\mathrm{A}_{1}$ and $\mathrm{A}_{2 \mathrm{~A}}$ ARs, following the procedure described previously [22]. Each tube in the binding assay contained $100 \mu \mathrm{L}$ of membrane suspension ( $20 \mu \mathrm{g}$ of protein), $50 \mu \mathrm{L}$ of agonist radioligand, and $50 \mu \mathrm{L}$ of increasing concentrations of the test ligands in Tris- $\mathrm{HCl}$ buffer $(50 \mathrm{mM}, \mathrm{pH} 7.5)$ containing $10 \mathrm{mM} \mathrm{MgCl}_{2}$. The concentration of the dendrimerligand complexes are measured by the concentration of the dendrimer, not the ligand. Therefore, all $\mathrm{K}_{\mathrm{i}}$ values are measured as $K_{i}$ app values. Nonspecific binding was determined using a final concentration of $10 \mu \mathrm{M} 5$ '-N-ethylcarboxamidoadenosine diluted with the buffer. The mixtures were incubated at $25^{\circ} \mathrm{C}$ for $60 \mathrm{~min}$. Binding reactions were terminated by filtration through Whatman GF/B filters under a reduced pressure using a MT-24 cell harvester (Brandell, Gaithersburg, MD). Filters were washed three times with $5 \mathrm{~mL}$ of $50 \mathrm{mM}$ ice-cold Tris-HCl buffer $(\mathrm{pH}$ $7.5)$. The radioactive agonists $\left[{ }^{3} \mathrm{H}\right] 2$-chloro- ${ }^{6}{ }_{-}$ cyclopentyladenosine and $\left[{ }^{3} \mathrm{H}\right] 2-(4$-(2-carboxyethyl)phenylethylamino)-5'-N-ethylcarboxamido-adenosine were used for the $A_{1}$ and $A_{2 A}$ assays, respectively. All of the filters were washed 3 times with Tris- $\mathrm{HCl}, \mathrm{pH}$ 7.5. Filters for 
$A_{1}$ and $A_{2 A} A R$ binding were placed in scintillation vials containing $5 \mathrm{~mL}$ of Hydrofluor scintillation buffer and counted using a Perkin Elmer Liquid Scintillation Analyzer. Filters for $\mathrm{A}_{3} \mathrm{AR}$ binding were counted using a Packard Cobra II $\gamma$-counter. The $\mathrm{K}_{\mathrm{i}}$ values were determined using GraphPad Prism for all assays.

\section{cAMP Assays}

CHO cells expressing either the $\mathrm{A}_{1}$ or $\mathrm{A}_{3} \mathrm{AR}$ were seeded in 24 well plates and incubated at $37^{\circ} \mathrm{C}$ overnight. The following day the medium was removed and replaced with DMEM containing $50 \mathrm{mM}$ HEPES, $10 \mu \mathrm{M}$ rolipram, $3 \mathrm{U} /$ $\mathrm{ml}$ adenosine deaminase and increasing concentrations of the compounds. After a $30 \mathrm{~min}$ incubation at $37^{\circ} \mathrm{C}, 10$ $\mu \mathrm{M}$ of forskolin was added to stimulate cAMP levels, and the cells were incubated at $37^{\circ} \mathrm{C}$ for an additional $15 \mathrm{~min}$. The medium was removed, and the cells were lysed with $200 \mu \mathrm{l}$ of $0.1 \mathrm{M} \mathrm{HCl} .100 \mu \mathrm{l}$ of the $\mathrm{HCl}$ solution was used in the Sigma Direct cAMP Enzyme Immunoassay following the instructions provided with the kit. The results were interpreted using a Bio-Tek Instruments ELx808 Ultra Microplate reader at $405 \mathrm{~nm}$.

\section{[35S]GTP/S Binding Assay}

[35S]GTP $\gamma$ S binding was measured in $200 \mu \mathrm{l}$ of buffer containing $50 \mathrm{mM}$ Tris- $\mathrm{HCl}(\mathrm{pH} 7.4), 1 \mathrm{mM}$ EDTA, $1 \mathrm{mM}$ $\mathrm{MgCl}_{2}, 10 \mu \mathrm{M}$ GDP, $1 \mathrm{mM}$ dithiothreitol, $100 \mathrm{mM} \mathrm{NaCl}$, 3 units/ml adenosine deaminase, $0.2 \mathrm{nM}\left[{ }^{35} \mathrm{~S}\right] \mathrm{GTP} \gamma \mathrm{S}$, $0.004 \%$ CHAPS, $0.5 \%$ bovine serum albumin and increasing concentrations of the ligands. Samples were started by addition of the membrane suspension (5-10 $\mu$ g protein/ tube) to the test tubes and incubated at $25^{\circ} \mathrm{C}$ for $30 \mathrm{~min}$. The assay was terminated by rapid filtration through Whatman GF/B filters, pre-soaked in $50 \mathrm{mM}$ Tris- $\mathrm{HCl}(\mathrm{pH}$ 7.4) containing $5 \mathrm{mM} \mathrm{MgCl}_{2}$ and $0.02 \%$ CHAPS. Nonspecific binding of [ $\left.{ }^{35} \mathrm{~S}\right] \mathrm{GTP} \gamma \mathrm{S}$ was measured in the presence of $10 \mu \mathrm{M}$ unlabelled GTP $\gamma$ S. After the filters were washed, they were placed in scintillation vials containing $5 \mathrm{~mL}$ of Hydrofluor scintillation buffer and counted using a Perkin Elmer Liquid Scintillation Analyzer. The $\mathrm{EC}_{50}$ values were determined using GraphPad Prism for all assays [23].

\section{Light and Fluorescent Microscopy}

$\mathrm{CHO}$ or $\mathrm{CHO} \mathrm{A}$ cells were seeded on a cover disk in a 6 well dish $(250,000$ cells per well). After the cells were incubated for 24 hrs at $37^{\circ} \mathrm{C}$, the medium was removed and replaced with DMEM containing $10 \mu \mathrm{M}$ of the 15 or 17. The cells were incubated for $1 \mathrm{~h}$ at $37^{\circ} \mathrm{C}$ and washed one time with PBS. The images were taken with at 100x manification using a Zeiss AxioVision D1 Imager equipped with AxioVision 4.5 software.

\section{Abbreviations}

ADAC: $\quad N^{6}$-[4-[[[4-[[[(2-aminoethyl)amino]carbonyl]methyl]-anilino]carbonyl]methyl]phenyl]adenosine; AF488-TFP: Alexa-Fluor ${ }^{\circledast} 488$ carboxylic acid, 2,3,5,6tetrafluorophenyl ester, 5-isomer; AR: adenosine receptor; CHAPS: 3-[(3-cholamidopropyl)dimethylammonio]-1propanesulfonate hydrate; $\mathrm{CHO}$ : Chinese hamster ovary; DMEM: Dulbecco's Modified Eagle Media; DMF: $N, \mathrm{~N}$ dimethylformamide; DMSO: dimethyl sulfoxide; EDC: $N$ (3-dimethylaminopropyl)-N'-ethylcarbodiimide; EDTA: ethylenediaminetetraacetic acid; ERK: extracellular signalregulated kinase; ESI: electrospray ionization; GDP: guanosine 5'-diphosphate; GPCR: G protein-coupled receptor; $\quad\left[{ }^{3} \mathrm{H}\right] \mathrm{CCPA}: \quad$ 2-chloro- $\mathrm{N}^{6}$-cyclopentyladenosine; [ $\left.{ }^{3} \mathrm{H}\right] \mathrm{CGS} 21680$ : 2-[p-(2-carboxyethyl)phenylethylamino]-5'-N-ethylcarboxamido-adenosine; HEK: human embryonic kidney; HEPES: 4-(2-hydroxyethyl)-1-piperazineethanesulfonic acid; [125I]AB-MECA: [125I]-4-aminobenzyl-5'-N-methylcarboxamideoadenosine; MALDITOF: matrix assisted laser desorption/ionization time-offlight; MES: 2-(N-morpholino)ethanesulfonic acid; MS: mass spectrometry; NMR: nuclear magnetic resonance; PAMAM: poly(amidoamine); PyBOP: benzotriazol-1-yloxytripyrrolidinophosphonium hexafluorophosphate.

\section{Competing interests}

$\mathrm{KAJ}$ and AMK are listed as inventors on a related patent application assigned to the Department of Health and Human Services.

\section{Authors' contributions}

AMK did the pharmacological assays, chemical synthesis, experimental design, and manuscript preparation. ZGG helped with pharmacological assays and experimental design. JL completed the mass spectrometry characterization of dendrimer derivatives. AS helped with the fluorescent microscopy. KAJ assisted with the experimental design and manuscript preparation.

\section{Additional material}

\section{Additional file 1}

Supplementary figures 1-4. Figure S1: ESI (+) MS of G3 and G2.5 Dendrimers. Figure S2: ESI (+) MS of Compounds 12 and 13. Figure S3: ESI (+) MS of Compounds 16 and 17. Figure S4: Light and Fluorescent Microscopy of $\mathrm{CHO}$ or $\mathrm{CHO}_{3}$ cells with Compound 15. The cells were plated $24 \mathrm{~h}$ prior to the experiment. The cells were incubated for $1 \mathrm{~h}$ with the $10 \mu \mathrm{M}$ of 15 and imaged with light and fluorescent microscopy. A. $\mathrm{CHO} \mathrm{A}_{3}$ cells, fluorescent image $\mathrm{B}$. $\mathrm{CHO} \mathrm{A}_{3}$ cells, light image C. $\mathrm{CHO}$ cells, fluorescent image D. CHO cells, light image.

Click here for file

[http://www.biomedcentral.com/content/supplementary/14773155-6-12-S1.doc] 


\section{Acknowledgements}

This research was supported in part by the Intramural Research Program of the NIH, NIDDK. We are grateful to Dr. Noel Whittaker for help obtaining the mass spectrometry results and to Dr. Herman Yeh for help with the NMR spectra. We thank Dr. Andrei A. Ivanov (NIDDK) for helpful discussion.

\section{References}

I. Lee CC, MacKay JA, Frechet JM, Szoka FC: Designing dendrimers for biological applications. Nat Biotechnol 2005, 23: I5I 7-I526.

2. Lundquist JJ, Toone EJ: The cluster glycoside effect. Chem Rev 2002, 1 02:555-578.

3. Dear JW, Kobayashi $H$, Brechbiel MW, Star RA: Imaging acute renal failure with polyamine dendrimer-based MRI contrast agents. Nephron Clin Pract 2006, 103:45-49.

4. Kim Y, Hechler B, Klutz AM, Gachet C, Jacobson KA: Toward multivalent signaling across $G$ protein-coupled receptors from poly(amidoamine) dendrimers. Bioconjugate Chem 2008, | 9:406-4II.

5. Jacobson KA, Gao ZG: Adenosine receptors as therapeutic targets. Nat Rev Drug Discov 2006, 5:247-264.

6. Fredholm BB, IJzerman AP, Jacobson KA, Klotz KN, Linden J: International union of pharmacology. XXV. Nomenclature and classification of adenosine receptors. Pharmacol Rev 200I, 53:527-552.

7. Madi L, Cohen S, Ochayin A, Bar-Yehuda S, Barer F, Fishman P: Overexpression of $A_{3}$ adenosine receptor in peripheral blood mononuclear cells in rheumatoid arthritis: Involvement of nuclear factor-kappaB in mediating receptor level. J Rheumatol 2007, 34:20-26.

8. Hutchinson SA, Scammells PJ: $\mathbf{A}_{1}$ adenosine receptor agonists: Medicinal chemistry and therapeutic potential. Curr Pharm Des 2004, 10:2021-2039.

9. Matot I, Einav S, Weininger CF, Pearl RG, Abramovich R, Joshi BV, Jacobson KA: Lung injury following in-vivo reperfusion: Outcome at 27 hours post-reperfusion. Anesthesiology 2008, 109:269-278.

10. Bar-Yehuda S, Stemmer SM, Madi L, Castel D, Ochaion A, Cohen S, Barer F, Zabutti A, Perez-Liz G, Del Valle L, Fishman P: The $\mathbf{A}_{3}$ adenosine receptor agonist CFI 02 induces apoptosis of hepatocellular carcinoma via de-regulation of the Wnt and NFkappaB signal transduction pathways. Int J Oncol 2008, 33:287-295.

I I. Li AH, Chang L, Ji X, Melman N, Jacobson KA: Functionalized congeners of I,4-dihydropyridines as antagonist molecular probes for A3 adenosine receptors. Bioconjug Chem 1999, 1 0:667-677.

12. Jacobson KA, Zimmet J, Schulick R, Barone S, Daly JW, Kirk KL: Adenosine analogs with covalently attached lipids have enhanced potency at $\mathbf{A}_{1}$-adenosine receptors. FEBS Lett 1987, 225:97-102.

13. Niiya K, Jacobson KA, Silvia SK, Olsson RA: Covalent binding of a selective agonist irreversibly activates guinea pig coronary artery A2 adenosine receptors. Naunyn Schmiedebergs Arch Pharmacol 1993, 347:521-526.

14. Gao ZG, Blaustein JB, Gross AS, Melman N, Jacobson KA: N6-substituted adenosine derivatives: Selectivity, efficacy, and species differences at $\mathbf{A}_{3}$ adenosine receptors. Biochem Pharmacol 2003, 65:1675-I684.

15. von Lubitz DK, Lin RC, Bischofberger N, Beenhakker M, Boyd M, Lipartowska R, Jacobson KA: Protection against ischemic damage by adenosine amine congener, $a$ potent and selective adenosine AI receptor agonist. Eur J Pharmacol 1999, 369:313-317.

16. von Lubitz DK, Lin RC, Paul IA, Beenhakker M, Boyd M, Bischofberger $\mathrm{N}$, Jacobson KA: Postischemic administration of adenosine amine congener (ADAC): Analysis of recovery in gerbils. Eur J Pharmacol 1996, 3 1 6:17|-179.

17. Jacobson KA, Kirk KL, Padgett WL, Daly JW: Functionalized congeners of adenosine: Preparation of analogues with high affinity for $\mathbf{A}_{1}$-adenosine receptors. I Med Chem 1985, 28: $134 \mid-1346$.

18. Panchuk-Voloshina N, Haugland RP, Bishop-Stewart J, Bhalgat MK, Millard PJ, Mao F, Leung WY, Haugland RP: Alexa dyes, a series of new fluorescent dyes that yield exceptionally bright, photostable conjugates. J Histochem Cytochem 1999, 47: I I79-I I 88.

19. Chandrasekar D, Sistla R, Ahmad FJ, Khar RK, Diwan PV: Folate coupled poly(ethyleneglycol) conjugates of anionic poly(amidoamine) dendrimer for inflammatory tissue specific drug delivery. J Biomed Mater Res A 2007, 82:92-103.

20. Walsh MK, Wang $X$, Weimer BC: Optimizing the immobilization of single-stranded DNA onto glass beads. J Biochem Biophys Methods 2001, 47:221-231.

21. Kim Y, Klutz AM, Jacobson KA: Systematic investigation of polyamidoamine dendrimers surface-modified with poly(ethylene glycol) for drug delivery applications: Synthesis, characterization, and evaluation of cytotoxicity. Bioconjug Chem 2008, 19:1660-1672.

22. Perreira M, Jiang JK, Klutz AM, Gao ZG, Shainberg A, Lu C, Thomas $C]$, Jacobson KA: "Reversine" and its 2-substituted adenine derivatives as potent and selective $\mathbf{A} 3$ adenosine receptor antagonists. J Med Chem 2005, 48:4910-4918.

23. Lorenzen A, Beukers MW, Graaf PH van der, Lang $H$, van MuijlwijkKoezen J, de Groote M, Menge W, Schwabe U, IJzerman AP: Modulation of agonist responses at the $A_{1}$ adenosine receptor by an irreversible antagonist, receptor-G protein uncoupling and by the $\mathbf{G}$ protein activation state. Biochem Pharmacol 2002 , 64: $1251-1265$.

24. Kim Y, Klutz AM, Hechler B, Gao ZG, Gachet C, Jacobson KA: Application of the functionalized congener approach to dendrimer-based signaling agents acting through $A_{2 A}$ adenosine receptors. Purinergic Signal 2008.

25. Quintana A, Raczka E, Piehler L, Lee I, Myc A, Majoros I, Patri AK, Thomas T, Mule J, Baker JR Jr: Design and function of a dendrimer-based therapeutic nanodevice targeted to tumor cells through the folate receptor. Pharm Res 2002, 19:1310-1316.

26. Yang H, Lopina ST: Penicillin V-conjugated PEG-PAMAM star polymers. J Biomater Sci Polym Ed 2003, I 4: I043-1056.

27. Malik N, Wiwattanapatapee R, Klopsch R, Lorenz K, Frey H, Weener JW, Meijer EW, Paulus W, Duncan R: Dendrimers: Relationship between structure and biocompatibility in vitro, and preliminary studies on the biodistribution of $125 \mid$-labelled polyamidoamine dendrimers in vivo. I Control Release 2000, 65:133-148.

28. Gurdag S, Khandare J, Stapels S, Matherly LH, Kannan RM: Activity of dendrimer-methotrexate conjugates on methotrexatesensitive and -resistant cell lines. Bioconjug Chem 2006, I 7:275-283.

29. Stambaugh K, Jacobson KA, Jiang JL, Liang BT: A novel cardioprotective function of adenosine $A I$ and $A 3$ receptors during prolonged simulated ischemia. Am J Physiol 1997, 273:H50 I-505.

30. Silverman MH, Strand V, Markovits D, Nahir M, Reitblat T, Molad Y, Rosner I, Rozenbaum M, Mader R, Adawi M, Caspi D, Tishler M, Langevitz P, Rubinow A, Friedman J, Green L, Tanay A, Ochaion A, Cohen S, Kerns WD, Cohn I, Fishman-Furman S, Farbstein M, Yehuda SB, Fishman P: Clinical evidence for utilization of the $A_{3}$ adenosine receptor as a target to treat rheumatoid arthritis: Data from a phase II clinical trial. J Rheumatol 2008, 35:4I-48.

31. Cordeaux Y, Briddon SJ, Alexander SP, Kellam B, Hill SJ: Agonistoccupied $A_{3}$ adenosine receptors exist within heterogeneous microdomains of individual living cells. FASEB J 2008, 22:850-860.

32. Ivanov AA, Jacobson KA: Molecular modeling of a PAMAMCGS2 1680 dendrimer bound to an $A_{2 A}$ adenosine receptor homodimer. Bioorg Med Chem Lett 2008, I 8:43 I 2-43 I5.

33. Gandia J, Galino J, Amaral O, Soriano A, Lluís C, Franco R, Ciruela F: Detection of higher-order $G$ protein-coupled receptor oligomers by a combined BRET-BiFC technique. FEBS Letters 2008, 582:2979-2984. 